\title{
WASPAS ve CODAS Yöntemleri ile OECD Ülkelerinin Sağllk Göstergeleri Açısından Kıyaslamalı Analizi ${ }^{1}$
}

\section{Comparative Analysis of OECD Countries with WASPAS and CODAS Methods in Terms of Health Indicators}

\author{
Zeynep Özgül SAYGIN* \\ Nilsen KUNDAKCI**
}

\begin{abstract}
$\ddot{O} Z$
Bedenen ve ruhen iyi durumda olan sağglklı bireylerden oluşan toplumlar, refah ve gelişsişlik düzeyleri açısından iyi bir konuma sahiptir. Bu nedenle sağllk alanında yapılacak olan her türlü iyileşme ve gelişme ilk olarak bireyleri ve daha sonra toplumları iyi yönde etkileyecektir. Bu çallşmanın amacı, OECD'ye üye olan 36 ülkenin belirlenen sağllk gösterge kriterleri altında değerlendirilerek sıralamalarının elde edilmesidir. Değerlendirmede kullanılan kriterlerin ă̆ırlkklarını belirlemek için SWARA (Step-wise Weight Assessment Ratio Analysis) yöntemi kullanılmış daha sonra literatürde yeni geliştirilen Çok Kriterli Karar Verme (ÇKKV) yöntemlerinden WASPAS (Weighted Aggregated Sum Product Assessment) ve CODAS (Combinative Distance-Based Assessment) kullanılarak ülkelerin siralama sonucunda nerede yer aldiklart belirlenmiştir. Kullanılan yöntemler sonucu elde edilen sıralamalar arasındaki ilişkiyi belirlemek için Spearman korelasyon katsaylsindan yararlanılmıștır.
\end{abstract}

ANAHTAR KELIMELER

SWARA, WASPAS, CODAS, Sağllk Göstergeleri, OECD Ülkeleri

\begin{abstract}
Societies composed of physically and psychological healthy individuals have a good position in terms of welfare and development levels. Therefore, any improvement and development in the field of health will affect firstly individuals and then societies in good direction. The aim of this study is to obtain the rankings of 36 member countries of the OECD under the defined health indicator criteria. SWARA (Step-wise Weight Assessment Ratio Analysis) was used to determine the weights of criteria and then WASPAS (Weighted Aggregated Sum Product Assessment) and CODAS (Combinative Distance Based Assessment) which are newly proposed Multi-Criteria Decision-Making (MCDM) methods in the literature were used to find the ranking of the countries. Spearman's correlation coefficient was used to determine the relationship between the obtained results.
\end{abstract}

KEYWORDS

SWARA, WASPAS, CODAS, Health Indicators, OECD Countries.

\begin{tabular}{|c|c|c|}
\hline & $\begin{array}{c}\text { Makale Geliş Tarihi / Submission Date } \\
\text { 30.07.2019 }\end{array}$ & $\begin{array}{c}\text { Makale Kabul Tarihi / Date of Acceptance } \\
20.04 .2020\end{array}$ \\
\hline Atıf & $\begin{array}{l}\text { Saygın, Z.Ö. ve Kundakcı, N. (2020). } \\
\text { Açısından Kıyaslamalı Analizi. Selçuk }\end{array}$ & $\begin{array}{l}\text { Yöntemleri ile OECD Ülkelerinin Sağlık Göstergeleri } \\
\text { mler Meslek Yüksekokulu Dergisi, } 23 \text { (1), 23-42. }\end{array}$ \\
\hline
\end{tabular}

${ }^{1}$ Bu çalışma; Zeynep Özgül Saygın'nın 2019 yılında, Pamukkale Üniversitesi - Sosyal Bilimler Enstitüsünde, Nilsen KUNDAKCI'nın danışmanlığında hazırladığı "OECD Ülkelerinin Sağlık Göstergeleri Açısından Bütünleşik Çok Kriterli Karar Verme Yaklaşımı ile Analizi” başlıklı yüksek lisans tezinden üretilmiştir.

*Yüksek Lisans Öğrencisi, Pamukkale Üniversitesi, Sosyal Bilimler Enstitüsü, Denizli, e-posta: zosaygin@ gmail.com, ORCID: 0000-0003-3831-6142

** Doç. Dr., Pamukkale Üniversitesi, İ̈BF, İşletme Bölümü, Denizli, e-posta: nilsenk@ pau.edu.tr, ORCID: 0000-0002-7283-320X 


\section{GIIRIŞ}

Sağlık kavramı Dünya Sağlık Örgütü tarafından 1946'da yapılan tanıma göre; yalnızca sakatlık ve hastalık halinin olmayışı değil, aynı zamanda bedensel, ruhsal, zihinsel ve sosyal olarak tam bir iyilik halidir (Kesgin ve Topuzoğlu, 2006: 47). Sağlık hizmetleri ülkelerin gelişmişlik düzeyleri hakkında bilgi vermektedir. Ekonomik ve sosyal açıdan refah düzeyleri iyi olan toplumların aynı zamanda sağlık hizmetleri de iyidir. Ülkelerin sağlık göstergeleri altında sergilemiş oldukları performansların ölçülmesi sonucunda elde edilen veriler ile izlenen sağlık politikasında değişikliğe gereksinim olup olmadığı, ülkenin sağlık düzeyinin ne durumda olduğu ve y1llar içerisinde ne gibi değişiklikler meydana geldiği görülmektedir. Aynı zamanda ülkeler arasında sağlık düzeyleri karşılaştırılabilmektedir. Ülkelerin birbiriyle kıyaslanabilmesi ve gelişmişlik düzeyleri hakkında bilgi sahibi olunması açısından standart, nicel ve objektif olan bir takım sağlık göstergeleri bulunmaktadır. Sağlık göstergeleri direkt ve endirekt olmak üzere iki temel amaca hizmet etmektedir. Ölüm, hastalık, sağlık hizmeti konularında direkt ve sosyal, ekonomik düzey, eğitim gibi konularda endirekt olarak amaca hizmet etmektedir (Aslan ve Uyar, 2016: 1132).

Sağlık alanında literatürde ÇKKV yöntemlerini kullanarak farklı uygulamaları ele alan çalışmalar bulunmaktadır. Örneğin, Shieh ve diğ. (2010), hastane hizmet kalitesine etki eden temel faktörleri tespit etmek için bir anket çalışması yapmışlar ve ana kriterler bulunduktan sonra DEMATEL yöntemini uygulamak için ikinci anketi yaparak kriterlerin önemini değerlendirmişlerdir. Kuo ve diğ. (2011), çalışmalarında ANP yönteminden faydalanarak, yaşlı hastaların ayakta tedavi görmelerine yönelik hizmet kalitesini değerlendirmişlerdir. Taghipour ve diğg. (2011), tıbbi cihazların önem derecelerine göre değerlendirilmesinde AHP yönteminden yararlanmışlardır. Topaloğlu ve diğ. (2012), iki Türk sağlık ocağı web sitesinin değerlendirilmesinde çeşitli kullanılabilirlik ve işlevsellik etmenleri arasındaki karmaşık ilişkileri saptamak amacıyla ANP yöntemini kullanmışlardır. Gül ve diğ. (2012), hastane acil bölümü için 3 kriter altında 10 farklı senaryo arasından en uygun olanının seçimini gerçekleştirmişlerdir. Kriterlerin ağırlıklarının belirlenmesinde bulanık AHP yönteminden, senaryoların değerlendirilmesi için VIKOR ve PROMETHEE yöntemlerinden yararlanılmış ve iki yöntem sonuçları karşılaştırılmıştır. Mohamed Riyazh Khan ve diğ. (2012), kurumsal hastanelerin hizmet kalitesini değerlendirmek için AHP yönteminden yararlanmışlardır. Özkan (2013), beş farklı sağlık hizmeti atık işleme seçeneğini ANP ve ELECTRE yöntemleri ile değerlendirmiştir. Tang (2013), çalışmasında Çin'in kurumsal sağlık hizmeti sağlayıcısı seçiminde AHP yönteminden yararlanmışıır. Hajrahimi ve diğ. (2013), İran'da seçilen üç tıp merkezinin sağlık bilgi güvenliğini bulanık AHP ve TOPSIS yöntemlerini kullanarak kontrol etmeyi amaçlamışlardır. Önder ve diğ. (2014), hemşirelik mesleği seçimini etkileyen faktörlerin önceliklendirilmesinde AHP yöntemini kullanmışlardır. Whiting ve dĭg . (2011), 2030 yılı için diyabet hasta sayılarını tahmin etmede AHP yönteminden faydalanmışlardır. Wollmann ve diğ. (2014), AHP yöntemi ile sağlı sigortası şirketlerinin imajlarını değerlendirmişlerdir. Önder ve diğg. (2014), üniversite hastanesinde hemşirelerde strese yol açan nedenlerin önem sıralamasında 7 adet ana stres göstergesi ve bu göstergelere bağl1 olarak 34 alt faktörün önem düzeylerinin belirlenmesinde AHP yöntemini kullanmışlardır. Uyan ve Yalpır (2016), Coğrafi Bilgi Sistemleri (CBS) ile entegre AHP yöntemini kullanarak Konya sınırları içerisinde tıbbi atık sterilizasyon tesisine uygun yerleri belirlemeyi amaçlamışlardır. Aytekin (2016), Eskişehir'de yer alan 3 adet kamu ve 5 adet özel hastanenin sıralamasını MULTIMOORA yöntemi ile elde etmiştir. Türeli ve Davraz (2016), özel bir hastane için uygun personel seçiminde AHP ve VIKOR yöntemlerini kullanmışlardır. Aytaç Adalı (2016), özel bir hastane için servis hemşiresi seçiminde EVAMIX ve TODIM yöntemlerinin kullanılmasını önermiştir. Kalhor ve diğ. (2016), çalışmalarında Doğu Akdeniz bölgesinde bulunan 21 ülkeyi, belirlenen sağlı göstergeleri ile TOPSIS ve AHP yöntemini kullanarak sıralamışlardır. Cihan ve diğ . (2017), devlet hastanesi için ekokardiyografi cihazının seçim problemine TOPSIS yöntemi ile çözüm aramışlardır. Bulut ve Durur (2017), Türkiye'nin sağlık turizm performansını TOPSIS yöntemi ile değerlendirmişlerdir. Boz ve Önder (2017), OECD ülkelerinin sağlık sistemi etkinliğini ölçmek için VZA yöntemini kullanmışlardır. Türkoğlu (2018), 26 Avrupa ülkesinin performansını 7 sağlık göstergesini dikkate alarak TOPSIS yöntemiyle değerlendirmiştir.

$\mathrm{Bu}$ çalışmada, literatürde yapılan çalışmalardan farklı olarak OECD örgütüne üye ülkelerin belirlenen sağlık göstergeleri altında göstermiş oldukları performans sıralamaları belirlenerek Türkiye'nin sıralama sonucu diğer üye ülkelerle karşılaştırılmıştır. OECD örgütüne üye otuz altı ülke; sağlık harcamaları, hastane yatak sayısı, doktor sayısı, hemşire sayısı, doğumda beklenen yaşam süresi, bebek ölüm oranları, tıbbi teknoloji ve tıp mezunları kriterleri altında değerlendirilmiştir. Öncelikle sağlık göstergelerinin önem düzeylerinin belirlenmesinde SWARA yönteminden yararlanılmış ve ülkeler arası sıralama sonuçlarının belirlenmesinde WASPAS ve CODAS yöntemleri kullanılmıştır. Kullanılan yöntemler sonucu elde edilen sıralamalar arasındaki ilişki Spearman korelasyon katsayısı ile hesaplanmıştır. Bu çalışma, ülkelerin sağlık 
alanında diğer ülkelere göre konumunun belirlenmesi, izlemiş oldukları sağlık politikalarında değişikliğe gereksinim olup olmadığına karar verilmesi, bu alandaki gerekli iyileştirmeler için adım atılması ve farklı yıllarda elde edilen sıralamalar ile ülkenin şu anki konumunun karşılaştırılması açısından önem taşımaktadır. $\mathrm{Bu}$ çalışmada diğer bir amaç ise nispeten yeni ÇKKV yöntemleri olan SWARA yöntemi ile WASPAS ve CODAS yöntemlerini entegre ederek literatüre katkı sağlamaktır.

$\mathrm{Bu}$ çalışma, beş bölümden oluşmaktadır. Birinci bölümde, sağlık göstergeleri hakkında bilgi verilerek ilgili literatür taraması sunulmuş ve bu çalışmada kullanılan sağlık göstergeleri tanımlanmıştır. İkinci bölümde, kriter ağırlıklarının belirlenmesinde kullanılacak SWARA yöntemi açıklanmış, üçüncü bölümde OECD ülkelerinin sıralanmasında kullanılacak olan ilk yöntem olan WASPAS yöntemine yer verilmiştir. Dördüncü bölümde, CODAS yöntemi açıklanmış ve yöntemde izlenecek adımlar anlatılmıştır. Beşinci bölümde, uygulamaya yer verilmiş, OECD ülkelerinin sağlı göstergeleri açısından sıralamaları WASPAS ve CODAS yöntemleri yardımıyla elde edilmiştir. Sonuç kısmında ise uygulama sonucu elde edilen ülke sıralamaları yorumlanmış ve ülkeler için sağlık alanında yapılması gereken iyileştirme tavsiyelerine yer verilmiştir.

\section{SAĞLIK GÖSTERGELERİ}

Ülkelerin gelişmişlik düzeyini belirleyerek aralarında kıyaslama yapabilmek için bazı kriterlere ihtiyaç duyulmaktadır ve bunlar sağlık göstergeleri olarak tanımlanmaktadır. Sağlık göstergelerinin, ülkeler açısından büyük öneme sahip olmasının nedenlerinden bazıları; daha iyi sağlık hizmeti sağlamaya yarayan etkin bir sağlık hizmet planlamasının yapılabilmesi, sağlık problemlerinin daha iyi tespit edilebilmesi ve ülkelerin sağlık açısından performanslarının karşılaştırılabilmesi olarak sıralanabilir. Sağlık göstergeleri, ülkenin mevcut durumunu göstermenin yanında belirli zaman aralıklarında meydana gelen değişimlerin ve performans değerlerinin belirlenmesine yardımcı olmaktadır. Bunların yanında, sağlık sektöründe devlet politikalarının etkin bir şekilde belirlenmesinde fayda sağlamaktadır. Ülkeler arasında ekonomik, kültürel ve sosyal farklılıklar bulunduğu için bu sağlık göstergeleri de ülkeden ülkeye değişiklik gösterebilmektedir.

$\mathrm{Bu}$ çalışmada ülkelerin analizinde kullanılan sağlık göstergeleri belirlenirken literatürdeki çalışmalar ve alanında uzman kişilerin görüşleri dikkate alınmıştır. Kriterlerin belirlenmesinde dikkate alınan bu çalışmalar şu şekilde özetlenebilir: Puig-Junoy (1998) Veri Zarflama Analizi (VZA) ile OECD ülkelerinin sağlık göstergeleri açısından etkinlik analizini yapmıştır. Çalışmasında girdi olarak; bin kişi başına düşen hekim sayısı, bin kişi başına düşen hekim dışı sağlık personeli sayısı, kişi başına düşen hastane yatağı sayısı, sağlık hizmetleri tüketim düzeyi, kişi başı alkol ve sigara tüketim düzeyi, çıktı olarak ise; doğumda beklenen yaşam yılı farkını (kadın-erkek) dikkate almıştır. Retzlaff-Roberts ve diğ. (2004), çalışmalarında VZA yöntemini kullanarak OECD ülkelerini sağlık göstergeleri altında değerlendirmiştir. Çalışmada kullanılan değişkenler; bin kişiye düşen hekim ve hasta yatağı sayısı, bir milyon kişiye düşen MRI sayısı, GSYİH'den sağlık harcamalarına ayrılan pay, bebek ölüm hızı, doğumda beklenen yaşam süresi, okul beklentisi, gini katsayısı ve sigara kullanım oranı şeklindedir. Afonso ve Aubyn (2005) Free Disposable Hull (FDH) ve VZA yöntemlerini kullanarak OECD ülkelerini sağlık göstergeleri açısından değerlendirmiştir. Yapılan çalışmada girdi olarak; bin kişi başına düşen hastane yatağı, hekim ve hemşire sayıları, çıktı olarak ise; bebek yaşam oranı, doğumda beklenen yaşam süresi, anne ölüm oranı belirlenmiştir. Afonso ve Aubyn (2006), çalışmalarında VZA Yöntemi ile OECD ülkelerini değerlendirmiştir. Çalışmada girdi olarak; bin kişi başına düşen pratisyen hekim, hemşire, tıbbi tedavide kullanılan yüksek teknolojili araç ve akut tedavi yatağı sayıları, çıktı olarak; bebek yaşam oranı, doğumda beklenen yaşam süresi, ortalama yaşam süresi sağlık göstergelerini dikkate almışlardır. Chu $\mathrm{Ng}$ (2008), Malmquist toplam faktör verimlilik endeksi (TFV) ile Çin Bölgelerini sağlık göstergeleri altında değerlendirmiştir. Çalışmada girdi olarak; bin kişi başına düşen hekim, hemşire, hastane yatağı ve sağlik personeli sayıları, çıktı olarak ayakta ve yatarak tedavi sayıları, ölüm oranı belirlenmiştir. Özdemir (2009), VZA ve CCR Yaklaşımını kullanarak Karadeniz Ekonomik İşbirliği Teşkilatı üyelerini sağlık göstergeleri açısından değerlendirmiştir. Çalışmasında girdi olarak; kişi başına yapılan sağlık harcaması, bin kişi başına düşen doktor sayısı, bin kişi başına düşen hastane yatak sayısı, çıktı olarak ise; nüfus ve sağlıklı beden yaşını dikkate almıştır. Ersöz (2009), Kümeleme işleminde aşamalı (hiyerarşik) kümeleme yöntemi, aşamalı olmayan yöntemlerden K-ortalamalar kümeleme, Medoid kümeleme yöntemlerinden yararlanarak OECD ülkelerini; toplam sağlık harcamalarının GSYH içindeki oranı, kişi başına düşen sağlık harcaması, doğumda beklenen yaşam süresi ve bebek ölüm hızı göstergeleri altında incelemiştir. Kocaman ve diğg. (2012), çalışmalarında VZA Yöntemi ve CCR Yaklaşımı ile OECD ülkelerinin sağlık açısından etkinliğini değerlendirirken girdi olarak; bin kişi başına düşen hekim sayısı, bin kişi başına düşen hastane yatağı sayısı, kişi başına düşen sağlık harcaması, GSYİH'den sağlık harcamalarına ayrılan pay, çıtı olarak ise; doğumda beklenen yaşam süresi, beş yaş altı ölüm oranını dikkate almışlardır. Girginer (2013), çalışmasında çok boyutlu ölçekleme analizi ve hiyerarşik olmayan kümeleme analizi ile Türkiye ve AB ülkelerini; doğumda yaşam

Selçuk Üniversitesi Sosyal Bilimler Meslek Yüksekokulu Dergisi, Yıl: 2020 Cilt: 23 Sayı:1 
beklentisi, bin canlı doğumda 5 yaşın altındaki çocuklarda ölüm oranı, bin nüfus başına 15-59 yaş arası çocuklarda ölüm oranı, doğumda sağlıklı yaşam beklentisi, GSYİH'nın sağlık harcaması payı, toplam sağlık harcamalarının kişi başına yıllık payı, toplam sağlık harcamalarından kamu sağlık harcamaları kriterleri altında değerlendirmiştir. Alptekin ve Yeşilaydın (2015), çalışmalarında Bulanık c-ortalamalar kümeleme analizi ve NCSS 10 paket programını kullanarak OECD ülkelerinin sağlık göstergeleri açısından etkinlik analizini yapmışlardır. Çalışmalarında; bin kişiye düşen hekim sayısı ve hasta yatağı sayısı, kişi başı sağlık harcaması, günlük sigara içen 15 yaş üstü erişkinlerin yüzdesi, kişi başı meyve tüketimi, kızamık aşısı olan çocukların yüzdesi, karbonmonoksit (CO) emisyonu, 5-39 yaş arası beklenen okullaşma oranı, doğumda beklenen yaşam süresi ve anne ölüm hızını gösteren verileri dikkate almışlardır. Mut ve Akyürek (2017), OECD ülkelerini sağlık göstergeleri açısından analiz ederken hiyerarşik kümeleme yöntemi, K-ortalama kümeleme yöntemlerinden yararlanmışlardır. Hekim sayısı, hasta yatağı sayısı, GSYİH'den sağlığa ayrılan pay, kızamık aşısı olan çocukların yüzdesi, gini katsayıs1, günlük sigara içen 15 yaş üstü erişkinlerin yüzdesi, 25-64 yaş üstü erişkinlerde okullaşma oranı, doğumdan beklenen yaşam yılı ve bebek ölüm hızını gösteren veriler dikkate alınarak analiz edilmiştir. Şener ve Yiğit (2017), çalışmalarında VZA, CCR ve BCC modelini kullanarak OECD ülkelerinin sağlık sistemlerinin teknik verimliliğini analiz etmişlerdir. Bu çalışmada girdi olarak; kişi başına düşen hastane yatağı sayısı, kişi başına düşen hekim sayısı, kişi başına düşen sağlık harcaması, kişi başına düşen MRI sayısı ve sigara kullanım oranı, çıktı olarak ise; Bebek ölüm oranı ve sağlıklı yaşam beklentisini göstermekte olan veriler dikkate alınmıştır. Göztepe (2017), çalışmasında OECD Ülkelerini sağlık göstergeleri açısından değerlendirirken VIKOR ve TOPSIS yöntemlerini kullanmıştır. Çalışmada; özel sektör, kamu ve kişi başına düşen sağlık harcamaları, doğum ve ölüm oranları, doktor, hemşire/ebe, yatak ve geliştirilmiş sanitasyon tesis sayılarını gösteren veriler yer almaktadır.

$\mathrm{Bu}$ çalışmada ise literatür taraması ve uzman görüşlerinden yararlanarak aşağıda belirtilen sağl1k göstergeleri dikkate alınmıştır. Bu belirlenen sağlık göstergeleri altında OECD ülkelerinin sıralamalarına ulaşılarak kıyaslamalı analizleri yapılmıştır.

Sağlık harcamaları: Sağlık harcamaları, kişisel sağlık bakımı (iyileştirici bakım, rehabilitasyon bakımı, uzun süreli bakım, yardımcı hizmetler ve tıbbi ürünler) ve toplu hizmetler (önleme ve halk sağlığı hizmetleri) dahil olmak üzere, sağlık hizmetlerinin nihai tüketimini ölçmektedir. Bu gösterge yatırımlara yapılan harcamalar hariç tutularak sağlık harcamalarının GSYİH'daki payı olarak ölçülmüştür.

Hastane Yatak Sayısı: Bir ülkede hastanede yer alan servis yatakları, rehabilitasyon bakım yatakları, uzun süreli bakım yatakları ve diğer yatakları içermektedir. Her bin kişi başına düşen hastane yatak sayısını göstermektedir.

Doktor Sayısı: Hasta bakımına doğrudan katkıda bulunan doktorlar dikkate alınmıştır. Bu gösterge bin kişi başına ölçülmüştür.

Hemşire Sayısı: Serbest çalışan hemşireler de dâhil olmak üzere hastalara doğrudan sağlık hizmeti sunan tüm hemşireleri içermektedir. Bu gösterge bin kişi başına ölçülmüştür.

Doğumda Beklenen Yaşam Süresi: Doğumda beklenen yaşam süresi, mevcut ölüm oranları değişmezse ortalama olarak bir yeni doğanın ne kadar süre yaşayabileceğini belirtmektedir. Doğumda beklenen yaşam süresi, artan yaşam standartlarına, gelişmiş yaşam tarzına ve daha iyi eğitim ile kaliteli sağlık hizmetlerine bağlı olarak değişmektedir. Bu gösterge kadın ve erkek toplam bazda ölçülmüştür.

Bebek Ölüm Oranları: Bebek ölümleri, bir yaşın altındaki çocukların ölüm sayısı olarak tanımlanmaktadır ve bebek ölüm oranları 1000 canlı doğum başına ölçülmektedir.

Tıbbi Teknoloji: Tıbbi teknoloji hastalıkların tanısı ve tedavisinde, sağlık problemlerini çözmek için sağlık personeli tarafından kullanılan yöntemlerdir. Tıbbi malzeme ve cihazları, cerrahi yöntem ve ilaçları kapsamaktadır.

Tıp Mezunları: Tıp mezunları, belirli bir yıldaki tıp fakültelerinden veya benzeri kurumlardan mezun olan öğrenci sayısını göstermektedir. Bu gösterge 100.000 kişi başına ölçülmüştür.

\section{SWARA YÖNTEMI}

SWARA, (Step-wise Weight Assessment Ratio Analysis) yöntemi 2010 yllında Keršulienè, Turskis ve Zavadskas tarafından geliştirilmiştir. Uygulama maliyetinin düşük olması, basit oluşu ve karar vericiye kriterlerin önem düzeylerinin belirlenmesinde daha çok olanak tanıması gibi nedenlerle birçok probleme çözüm aranırken kullanılmıştır (Özbek, 2017: 43). SWARA yönteminde, kriterlerin ve alternatiflerin değerlendirilmesinde belirsizliklerin üstesinden gelmek için basit göreli karşılaştırmalar kullanılmakta, uzmanların bilgi ve birikimlerinden faydalanılarak kriter ağırlıkları belirlenmektedir (Keršulienè ve diğ., 2010: 410; Nezhad, 2015: 1124). 
Literatürde SWARA yöntemini kriter ağırlıklarını belirlemek için kullanarak diğer ÇKKV yöntemler ile entegre şekilde uygulayan çalışmalar yer almaktadır. Örneğin, Zolfani ve Zavadskas (2013), SWARA ve COPRAS yöntemlerinin bütünleşik olarak ele alıp kırsal alanlarda bina yapılarının sağlamlığı ve sürdürülebilirliğine ilişkin gelişme alternatiflerini değerlendirmişlerdir. Zolfani ve diğ. (2013), ürünlerin tasarımında kullanılacak kriterlerin önem düzeylerini SWARA yönteminden faydalanarak belirlemişlerdir. Zolfani ve Bahrami (2014), İran'da Biyomedikal Mikro Elektromekanik Sistemler, Nano Teknoloji, Biyoteknoloji ve Biyomedikal Mühendisliği gibi dört yüksek teknoloji endüstrisi arasından yatırım önceliği için değerlendirme yaparken SWARA ve COPRAS yöntemlerinden yararlanmışlardır. Stanujkic ve diğ. (2015), paketlemede ideal tasarımın bulunması için kriterlerin önem düzeylerini belirlemede SWARA yöntemini kullanmışlardır. Tuş Işık ve Adalı (2016), SWARA ve OCRA yöntemlerinin bütünleşik olarak uygulanabilirliğini bir otel seçim probleminde göstermişlerdir. Çakır ve Karabıyık (2017), bulut depolama adı verilen hizmet sağlayıcıları arasından en iyisini seçmek için SWARA ve COPRAS yöntemlerini bir arada kullanmışladır. Çakır ve Akar (2017), Aydın'da faaliyet gösteren bir işletme için CNC makinesinin seçiminde kriterlerin ağırlıklarını SWARA yöntemi yardımıyla hesaplamışlar ve TOPSIS yöntemiyle alternatifler arasından en uygun olanı seçmişlerdir. Çakır (2017), kentsel dönüşüm kapsamında yıkımı gerçekleştirilen riskli binanın yerine yeni bir bina inşası için en iyi müteahhit firmasının seçiminde SWARA ve Gri İlişkisel Analiz yöntemlerinden yararlanmıştır. Ayyıldız ve Demirci (2018), şehirlerin yaşam kalitesini değerlendirmede SWARA ve TOPSIS yöntemlerini kullanmıştır. Çakır (2018a) Elektronik Belge Yönetim Sistemi (EBYS) yazılımı seçiminde, SWARA ve EDAS yöntemlerini bir arada kullanmıştır. Vesković ve diğ. (2018), SWARA ve MABAC yöntemleri ile Bosna-Hersek bölgesinde demiryolu şirketleri için yönetim modeli seçmişlerdir.

SWARA yöntemi ile kriterlerin göreceli ağırlıkları hesaplanırken izlenen adımlar aşağıda yer almaktadır (Özbek, 2017: 46).

1. Adım: İlk adımda, kriterler uzmanlar tarafından en önemli kriter başta, en az öneme sahip kriter sonda olmak üzere azalan önem derecesine göre sıralanır. Eğer birden fazla uzman tarafından kriterler değerlendirilecekse, her birinin kriterleri azalan düzeyde sıralanması istenir ve genel sıralama uzmanların belirlemiş oldukları kriter sıralamalarının geometrik veya aritmetik ortalaması alınarak elde edilir (Ruzgys ve diğ., 2014: 107).

2. Adım: Bütün kriterler için göreceli önem düzeyleri; $j$. kriter $(j+1)$. ile karşılaştırılarak $j$. kriterin $(j+1)$. kriterden ne düzeyde önemli olduğu belirlenerek hesaplanmaktadır (Özbek, 2017: 43). Beş ve beşin katları şeklinde belirlenen bu oran, Keršulienè ve diğ. (2010) tarafından "ortalama değerin karşılaştırmalı önemi" olarak adlandırılmıştır ve $S_{\mathrm{j}}$ ile gösterilmektedir.

3. Adım: Kriterler için $k_{j}$ katsayısı Eşitlik (1) yardımı ile belirlenir.

$$
k_{j}= \begin{cases}1 & j=1 \\ s_{j}+1 & j>1\end{cases}
$$

4. Adım: Önem vektörü olan $q_{j}$, değişkeni Eşitlik (2)'de görüldüğü gibi hesaplanır.

$$
q_{j}= \begin{cases}1 & j=1 \\ \frac{q_{j-1}}{k_{j}} & j>1\end{cases}
$$

5. Adım: Değerlendirme kriterlerine ait ağırlıklar, Eşitlik (3)'te gösterildiği gibidir.

$$
w_{\mathrm{j}}=\left\{\frac{q_{j}}{\sum_{k=1}^{n} q_{k}}\right.
$$

Burada; $w_{j}, j$.kriterin göreli ağırlı̆̆ını göstermektedir.

\section{WASPAS YÖNTEMI}

WASPAS (Weighted Aggregated Sum Product Assessment) yöntemi, Ağırlıklandırılmış Toplam Modeli (WSM), ve Ağırlıklandırılmış Çarpım Modeli (WPM)'nin birleştirilmesi sonucunda Zavadskas ve diğ. tarafından 2012 yılında geliştirilen bir yöntemdir (Çakır ve diğ., 2018: 604). Bu yöntem ile birlikte sıralama doğruluğunun arttırılması amaçlanmaktadır. Bu iki farklı modelin sonuçları göz önünde bulundurularak hesaplanan ağırlıklı bütünleştirilmiş fonksiyonun optimizasyonu ile alternatif sıralamasında yüksek tutarlılık elde edilmek istenmiştir (Aytaç Adalı ve Tuş Işık, 2017: 66).

Literatürde WASPAS yöntemini uygulayan farklı çalışmalar yer almaktadır. Chakraborty ve Zavadskas (2014), WASPAS yöntemi ile tam zamanlı üretim ortamında sekiz adet açıklayıcı örneği değerlendirmiştir. 
Chakraborty ve diğ. (2015), WASPAS yönteminin karar verme aracı olarak uygulanabilirliğini beş farklı örnek üzerinde göstermişlerdir. Zavadskas ve diğ. (2016), altı adet benzer tuğla evlerin iç ortamını değerlendirmek için WASPAS yöntemini kullanılmışlardır. Karabašević ve diğ. (2016), nitelikli personelin bulunması ve işe alınması sürecinde dört alternatif personelin performanslarını, yedi kriteri göz önünde bulundurarak SWARA ve WASPAS yöntemleriyle değerlendirmişlerdir. Can ve diğ. (2017), pim imalatı yapan bir işletme için oturma düzeneği seçiminde SWARA ve WASPAS yöntemlerini bir arada kullanmışlardır. Akçakanat ve diğ. (2017), büyük, orta ve küçük ölçekli bankaların performans değerlendirmelerini yaparken Entropi ve WASPAS yöntemlerini kullanmışlardır. Yurdoğlu ve Kundakcı (2017), SWARA ve WASPAS yöntemleri ile bir tekstil işletmesinin bir departmanı için en uygun sunucuyu seçmişlerdir. Tayalı (2017), tedarikçi seçim problemine WASPAS yöntemiyle çözüm aramıştır. Ayyıldız ve Murat (2017) WASPAS yöntemi ile Türkiye'de yer alan şehirlerin eğitim performanslarını analiz etmişlerdir. Baušys ve Juodagalvienè (2017), müstakil bir evin garaj yapımında uygun pozisyon seçimi için ANP ve WASPAS yöntemlerini kullanmıştır. Aytaç Adalı ve Tuş Işık (2017), bir tekstil işletmesinin konfeksiyon bölümü için tedarikçi seçiminde SWARA ve WASPAS yöntemlerinin uygulanabilirliğini göstermişlerdir. Çakır ve diğ. (2018), özel alışveriş sitelerini hizmet kalitesi kriterlerine göre SWARA ve WASPAS yöntemlerini bir arada kullanılarak değerlendirmiştir.

WASPAS yöntemini uygulamak için takip edilmesi geren adımlar aşağıdaki gibidir (Zavadskas ve diğ., 2012 ; Chakraborty ve Zavadskas, 2014):

1. Adım: İlk adımda karar matrisi $X$ oluşturulmaktadır.

$$
X=\left[X_{i j}\right]_{m x n}=\left[\begin{array}{ccc}
X_{11} & \cdots & X_{1 n} \\
\vdots & \ddots & \vdots \\
X_{m 1} & \cdots & X_{m n}
\end{array}\right] \quad(i=1,2, \ldots, m \text { ve } j=1,2, \ldots, n)
$$

Burada $x_{i j}\left(x_{i j} \geq 0\right)$ olup, $i$ 'ninci alternatifin $j$ 'ninci kriterdeki performansını göstermektedir.

2. Adım: Sonraki adımda normalizasyon işlemi gerçekleştirilirken kriterlerin fayda kriteri ya da maliyet kriteri oluşuna göre hesaplamaları Eşitlik (5) ve Eşitlik (6) yardımıyla yapılır.

Fayda kriteri için;

$$
n_{i j}=\frac{x_{i j}}{\max _{i} x_{i j}} \quad i=1,2, \ldots, m \text { ve } j=1,2, \ldots, n
$$

Maliyet kriteri için;

$$
n_{i j}=\frac{\min _{i} x_{i j}}{x_{i j}} \quad i=1,2, \ldots, m \text { ve } j=1,2, \ldots, n
$$

3. Adım: Ağırlıklandırılmış Toplam Modeline (WSM) göre bütün alternatifler için toplam göreceli önem değeri Eşitlik (7) ile hesaplanır ve $Q_{i}{ }^{(1)}$ simgesi ile ifade edilir.

$$
Q_{i}^{(1)}=\sum_{j=1}^{n} w_{j} \cdot n_{i j}
$$

Eşitlik (7)'de $w_{j}, j$.kriterin ağırlığını göstermektedir. Bu çalışmada kriter ağırlıkları SWARA yöntemi ile elde edilmiştir.

4. Adım: Ağırlıklandırılmış Çarpım Modeli (WPM) kullanılarak Eşitlik (8) yardımıyla ikinci göreceli önem değeri $Q_{i}^{(2)}$ hesaplanır.

$$
Q_{i}^{(2)}=\prod_{j=1}^{n} n_{i j}{ }^{w_{j}}
$$

5. Adım: WSM ve WPM modellerinin sonuçları ile hesaplanan alternatiflerin toplam göreli önemi Eşitlik (9) yardımı ile belirlenir.

$$
Q_{i}=\lambda Q_{i}^{(1)}+(1-\lambda) Q_{i}^{(2)}
$$

$Q_{i}$ simgesi $i$. alternatif için toplam göreli önemi belirtirken, $\lambda$ bu yöntemde kullanılan bir parametre olup 0 ile 1 arasında değere sahiptir. Belirtilen $\lambda$ değeri karar vericiye bağlı olarak değişiklik göstermektedir (Adalı ve Tuş Işık 2017: 67). $\lambda$ değerinin 0'a eşit olması durumunda model Ağırlıklandırılmış Çarpım Modeline, $\lambda$ değerinin 1'e eşit olması durumunda model Ağırlıklandırılmış Toplam Modeline dönüşür (Zavadskas ve diğ., 2012: 4).

6. Adım: Hesaplanan $Q_{i}$ değerleri içerisinde en yüksek değere sahip olan alternatif, en iyi alternatif olarak belirlenir. 


\section{CODAS YÖNTEMI}

CODAS (Combinative Distance-based Assessment) yöntemi, ÇKKV problemlerine çözüm getirmek üzere geliştirilen yeni bir yöntemdir. $\mathrm{Bu}$ yöntemde alternatiflerin tercih edilebilirliği iki ölçü kullanılarak belirlenmektedir. Birincil ölçü, alternatiflerin Öklid mesafesinin negatif- ideale uzaklığı ile ilgilidir. Bu tür bir mesafeyi kullanmak, kriterler için farksızlık alanı gerektirir. İkincil ölçü, normal kayıtsızlık alanıyla ilgili olan Taxicab mesafesidir. Negatif-ideal çözümden daha uzak mesafelere sahip olan alternatif daha önceliklidir (Keshavarz ve diğ., 2016: 29). Bu yöntemde iki alternatif Öklid mesafesine göre kıyaslanamazsa, ikinci ölçü olan Taxicab mesafesi kullanılır (Badi ve diğ., 2017: 30).

Literatürde CODAS yöntemini ele alan makaleler şu şekilde sıralanabilir: Keshavarz ve diğ. (2016), araştırmalarında negatif ideal çözüme göre hesaplanan Öklid ve Taxicab mesafelerini ele alan CODAS yönteminin uygulanabilirliğini iki örnekte göstermişlerdir. Badi ve diğ. (2017), bir demir çelik şirketinin tedarikçi seçiminde CODAS yönteminden yararlanmışlardır. Badi ve diğ. (2018), Libya'nın kuzeybatı kıyılarında tuzdan arındırma tesisi için en iyi yerin seçiminde CODAS yöntemini kullanmışlardır. Mathew ve Sahu (2018), CODAS, EDAS, WASPAS ve MOORA yöntemlerini kullanarak iki tane malzeme taşıma ekipmanı seçim problemini değerlendirmişlerdir.

CODAS yönteminin aşamaları aşağıda belirtildiği gibidir (Keshavarz ve diğ., 2016: 29).

1. Adım: Öncelikle Eşitlik (4)’te görüldüğü gibi karar matrisi oluş̧urulur.

2. Adım: Eşitlik (10) yardımıyla karar matrisi normalize edilir.

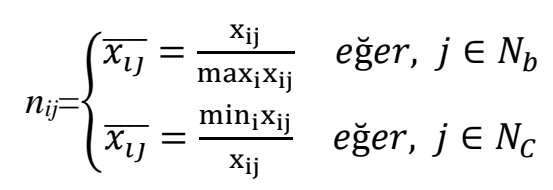

$N_{b}$ ve $N_{c}$ sırasiyla fayda ve maliyet kriterlerini temsil etmektedir.

3. Adım: Ağıllıklandırılmış normalize karar matrisi Eşitlik (11) yardımıyla hesaplanmaktadır.

$$
r_{i j}=w_{j .} n_{i j}
$$

$w_{j}\left(0<\mathrm{w}_{\mathrm{j}}<1\right) j$ 'ninci kriterin ağırlığını gösterir ve $\sum_{j=1}^{n} w_{j}=1$.

4. Adım: Negatif-ideal çözüm Eşitlik (12) ve Eşitlik (13) ile belirlenir.

$$
\begin{aligned}
& n s=\left[n s_{j}\right]_{1 \times n} \\
& n s_{j}=\min _{i} r_{i j}
\end{aligned}
$$

5. Adım: Eşitlik (14) ve Eşitlik (15) yardımıyla negatif ideal çözümden alternatiflerin Öklid ( $\left.\mathrm{E}_{i}\right)$ ve Taxicab $\left(T_{i}\right)$ mesafeleri hesaplanır.

$$
\begin{aligned}
& \mathrm{E}_{i}=\sqrt{\sum_{j=1}^{n}\left(r_{i j}-n s_{j}\right)^{2}} \\
& T_{i}=\sum_{j=1}^{n}\left|r_{i j}-n s_{j}\right|
\end{aligned}
$$

6. Adım: Göreceli değerlendirme matrisi Eşitlik (16) ve (17) ile oluşturulur.

$$
\begin{gathered}
R a=\left[h_{i k}\right]_{m x m} \\
h_{i k}=\left(E_{i}-E_{k}\right)+\left(\psi\left(E_{i}-E_{k}\right) \times\left(T_{i}-T_{k}\right)\right)
\end{gathered}
$$

Buradaki $\mathrm{k} \in\{1,2, \ldots, m\}$ ve $\psi$, iki alternatifin Öklid mesafelerinin eşitliğini tanımlamak için bir eşik fonksiyonunu belirtir ve Eşitlik (18)'de görüldüğü şekilde tanımlanır:

$$
\psi\left(E_{i}-E_{k}\right)= \begin{cases}1 \text { e } \breve{\mathrm{g}} \text { er } & \left|E_{i}-E_{k}\right| \geq \tau \\ 0 \text { e } \text { ğer } & \left|E_{i}-E_{k}\right|<\tau\end{cases}
$$

$\mathrm{Bu}$ fonksiyonda $\tau$ eşik parametresidir ve karar verici tarafından belirlenebilir. 0,01 ve 0,05 arasında seçilmesi tavsiye edilmektedir. Eğer iki alternatifin Öklid uzaklıkları arasındaki fark $\tau$ 'den küçükse bu iki alternatif aynı zamanda Taxicab uzaklığı ile de karşılaştırılır.

7. Adım: Bu adımda her bir alternatif için değerlendirme skoru Eşitlik (19) ile hesaplanır.

$$
H_{i}=\sum_{k=1}^{m} h_{i k}
$$


8. Adım: Her bir alternatif için hesaplanan değerlendirme skorları azalan şekilde sıralanır. En yüksek skora sahip olan alternatif en iyisi olarak belirlenir.

\section{UYGULAMA}

Uygulama bölümünde, OECD örgütüne üye otuz altı ülke; belirlenen kriterler altında değerlendirilmiş ve elde edilen sıralamalar doğrultusunda ülkeler karşılaştırılmıştır. Kriterlerin belirlenmesinde, literatür taraması ve uzman görüşleri göz önünde bulundurulmuştur. Sağlık alanında belirli bir bilgi birikimine sahip olan ve kriterlerin değerlendirilmesinde yer alan karar vericiler, sağlık sektöründe çalışmakta ve alanlarında uzman kişilerden oluşmaktadır. Bu karar vericilere ilişsin bilgiler Tablo 1'de görülmektedir:

Tablo 1. Karar Vericilere İlişskin Bilgiler

\begin{tabular}{ccccll}
\hline Kişiler & Cinsiyet & Yaşı & Çalışma Süreleri & Uzmanlık Alanı & Unvanı \\
\hline $\mathrm{KV}_{1}$ & Kadın & 57 & $32 \mathrm{y} 1$ & Göğüs Hastalıkları & Prof. Dr. \\
$\mathrm{KV}_{2}$ & Kadın & 46 & $23 \mathrm{yıl}$ & Göğüs Hatalıkları & Prof. Dr. \\
$\mathrm{KV}_{3}$ & Erkek & 51 & $26 \mathrm{yl}$ & Acil Tıp & Prof. Dr. \\
$\mathrm{KV}_{4}$ & Erkek & 38 & $15 \mathrm{y} ı$ & Çocuk Sağlı̆̆ı ve Hastalıkları & Doç. Dr. \\
$\mathrm{KV}_{5}$ & Kadın & 40 & $15 \mathrm{yll}$ & Aile Hekimliği & Doç. Dr. \\
$\mathrm{KV}_{6}$ & Erkek & 50 & $27 \mathrm{yıl}$ & Kardiyoloji & Prof. Dr. \\
\hline
\end{tabular}

Çalışmada kullanılacak olan sağlık göstergelerinden oluşan kriterler, $K_{1}$ Sağlık Harcamaları (Sağlık harcamalarının GSYIH'daki payı), $K_{2}$ Hastane Yatak Sayısı (1000 kişi başına), $K_{3}$ Doktor Sayısı (1000 kişi başına), $\mathrm{K}_{4}$ Hemşire Sayısı (1000 kişi başına), $\mathrm{K}_{5}$ Doğumda Beklenen Yaşam Süresi, $\mathrm{K}_{6}$ Bebek Ölüm Oranları (1000 canlı doğum başına), $\mathrm{K}_{7}$ Tıbbi Teknoloji, $\mathrm{K}_{8}$ Tıp Mezunları (100.000 kişi başına) olarak belirlenmiştir.

İlk olarak, sağlık göstergesi kriterlerinin ağırlıklarını belirlemede SWARA yöntemi kullanılmıştır. Daha sonra ÇKKV yöntemlerinden olan WASPAS ve CODAS yöntemleri kullanılarak ülkelerin sıralamaları belirlenmiştir. Elde edilen sıralama sonuçları arasındaki ilişkiyi belirlemek için Spearman Korelasyon Katsayısından faydalanılmıştır.

\subsection{SWARA Yöntemi ile Kriterlerin Ağırlıklarının Belirlenmesi}

SWARA yöntemi ile kriterlerin ağırlıklarının belirlenmesinin ilk adımında, altı karar vericiden sekiz kriteri önem derecesine göre sıralamaları istenmiştir ve kriterler için oluşturulan sıralama sonuçları Tablo 2'de gösterilmiştir.

Tablo 2. Karar Vericiler Tarafından Oluşturulan Kriter Sıralamaları

\begin{tabular}{lcccccc}
\hline Kriterler & $\mathbf{K V}_{\mathbf{1}}$ & $\mathbf{K V}_{\mathbf{2}}$ & $\mathbf{K V}_{\mathbf{3}}$ & $\mathbf{K V}_{\mathbf{4}}$ & $\mathbf{K V}_{\mathbf{5}}$ & $\mathbf{K V}_{\mathbf{6}}$ \\
\hline Sağlık Harcamaları $\left(\mathrm{K}_{1}\right)$ & 2 & 2 & 4 & 2 & 3 & 6 \\
Hastane yatak sayısı $\left(\mathrm{K}_{2}\right)$ & 3 & 6 & 7 & 5 & 7 & 5 \\
Doktor Sayısı $\left(\mathrm{K}_{3}\right)$ & 5 & 1 & 2 & 3 & 4 & 3 \\
Hemşire Sayısı $\left(\mathrm{K}_{4}\right)$ & 4 & 5 & 6 & 4 & 5 & 4 \\
Beklenen Yaşam Süresi $\left(\mathrm{K}_{5}\right)$ & 7 & 4 & 5 & 7 & 2 & 2 \\
Bebek Ölüm Oranları $\left(\mathrm{K}_{6}\right)$ & 1 & 3 & 1 & 1 & 1 & 1 \\
Tibbi Teknoloji $\left(\mathrm{K}_{7}\right)$ & 6 & 8 & 3 & 6 & 6 & 7 \\
Tip Mezunları $\left(\mathrm{K}_{8}\right)$ & 8 & 7 & 8 & 8 & 8 & 8 \\
\hline
\end{tabular}

İkinci adımda her bir karar verici, oluşturdukları sıralamalar doğrultusunda kriterleri kıyaslayarak göreli önem düzeyi $s_{j}$ değerlerini belirlemişlerdir. 
Tablo 3. Karar Vericiler Tarafından Oluşturulan Kriterlerin Göreceli Önem Düzeyi

\begin{tabular}{|c|c|c|c|c|c|c|c|c|c|c|c|c|}
\hline \multirow{2}{*}{$\begin{array}{l}\text { Önem } \\
\text { SIrası }\end{array}$} & \multicolumn{2}{|c|}{$\mathrm{KV}_{1}$} & \multicolumn{2}{|c|}{$\mathrm{KV}_{2}$} & \multicolumn{2}{|c|}{$\mathrm{KV}_{\mathbf{3}}$} & \multicolumn{2}{|c|}{$\mathrm{KV}_{4}$} & \multicolumn{2}{|c|}{$\mathrm{KV}_{5}$} & \multicolumn{2}{|c|}{$\mathrm{KV}_{6}$} \\
\hline & SK & $\mathbf{S}_{\mathbf{j}}$ & SK & $\mathbf{S}_{\mathbf{j}}$ & SK & $\mathbf{S}_{\mathbf{j}}$ & SK & $\mathbf{S}_{\mathbf{j}}$ & SK & $\mathbf{S}_{\mathbf{j}}$ & SK & $\mathbf{S}_{\mathbf{j}}$ \\
\hline 1 & $\mathrm{~K}_{6}$ & & $\mathrm{~K}_{3}$ & & $\mathrm{~K}_{6}$ & & $\mathrm{~K}_{6}$ & & $\mathrm{~K}_{6}$ & & $\mathrm{~K}_{6}$ & \\
\hline 2 & $\mathrm{~K}_{1}$ & 0,10 & $\mathrm{~K}_{1}$ & 0,05 & $\mathrm{~K}_{3}$ & 0,05 & $\mathrm{~K}_{1}$ & 0,10 & $\mathrm{~K}_{5}$ & 0,05 & $\mathrm{~K}_{5}$ & 0,05 \\
\hline 3 & $\mathrm{~K}_{2}$ & 0,10 & $\mathrm{~K}_{6}$ & 0,05 & $\mathrm{~K}_{7}$ & 0,05 & $\mathrm{~K}_{3}$ & 0,10 & $\mathrm{~K}_{1}$ & 0,05 & $\mathrm{~K}_{3}$ & 0,05 \\
\hline 4 & $\mathrm{~K}_{4}$ & 0,05 & $\mathrm{~K}_{5}$ & 0,1 & $\mathrm{~K}_{1}$ & 0,1 & $\mathrm{~K}_{4}$ & 0,10 & $\mathrm{~K}_{3}$ & 0,05 & $\mathrm{~K}_{4}$ & 0,10 \\
\hline 5 & $\mathrm{~K}_{3}$ & 0,05 & $\mathrm{~K}_{4}$ & 0,05 & $\mathrm{~K}_{5}$ & 0,05 & $\mathrm{~K}_{2}$ & 0,05 & $\mathrm{~K}_{4}$ & 0,10 & $\mathrm{~K}_{2}$ & 0,05 \\
\hline 6 & $\mathrm{~K}_{7}$ & 0,05 & $\mathrm{~K}_{2}$ & 0,05 & $\mathrm{~K}_{4}$ & 0,05 & $\mathrm{~K}_{7}$ & 0,05 & $\mathrm{~K}_{7}$ & 0,05 & $\mathrm{~K}_{1}$ & 0,05 \\
\hline 7 & $\mathrm{~K}_{5}$ & 0,05 & $\mathrm{~K}_{8}$ & 0,05 & $\mathrm{~K}_{2}$ & 0,05 & $\mathrm{~K}_{5}$ & 0,10 & $\mathrm{~K}_{2}$ & 0,05 & $\mathrm{~K}_{7}$ & 0,10 \\
\hline 8 & $\mathrm{~K}_{8}$ & 0,10 & $\mathrm{~K}_{7}$ & 0,05 & $\mathrm{~K}_{8}$ & 0,05 & $\mathrm{~K}_{8}$ & 0,10 & $\mathrm{~K}_{8}$ & 0,15 & $\mathrm{~K}_{8}$ & 0,15 \\
\hline
\end{tabular}

Örneğin 1. karar verici için $\mathrm{K}_{6}$ ile $\mathrm{K}_{1}$ kriterleri arasında kıyaslama sonucu oluşturulan önem düzeyi 0,10 iken; 2. karar verici için $\mathrm{K}_{3}$ ile $\mathrm{K}_{1}$ kriterleri arasındaki önem düzeyi 0,05 olarak belirlenmiştir. Daha sonraki adımda Eşitlik (1) yardımıyla $\mathrm{s}_{\mathrm{j}}$ değerleri kullanılarak, katsayı $\left(k_{j}\right)$ değerleri elde edilmiştir. Eşitlik (2) ile önem vektörü $\left(q_{i}\right)$ değerleri ve Eşitlik (3) ile kriterlerin ağırlıkları hesaplanmıştır. Aynı şekilde sırasıyla tüm karar vericiler için hesaplamalar yapılmıştır. Birinci karar vericiye ait hesaplamalar sonucu her bir kriter için elde edilen veriler Tablo 4'te görülmektedir.

Tablo 4. Birinci Karar Vericiye ait Kriter Ă̆ırlıklarının Hesaplanması

\begin{tabular}{lcccccc}
\hline Kriterler & Önem Sırası & Sıralı Ölçütler & $\boldsymbol{S}_{\boldsymbol{j}}$ & $\boldsymbol{K}_{\boldsymbol{j}}$ & $\boldsymbol{q}_{\boldsymbol{j}}$ & $\boldsymbol{w}_{\boldsymbol{j}}$ \\
\hline Sağlık Harcamaları $\left(\mathrm{K}_{1}\right)$ & 2 & $\mathrm{~K}_{6}$ & & 1,000 & 1,000 & 0,159 \\
Hastane yatak sayısı $\left(\mathrm{K}_{2}\right)$ & 3 & $\mathrm{~K}_{1}$ & 0,10 & 1,100 & 0,909 & 0,145 \\
Doktor Sayısı $\left(\mathrm{K}_{3}\right)$ & 5 & $\mathrm{~K}_{2}$ & 0,10 & 1,100 & 0,826 & 0,132 \\
Hemşire Sayısı $\left(\mathrm{K}_{4}\right)$ & 4 & $\mathrm{~K}_{4}$ & 0,05 & 1,050 & 0,787 & 0,125 \\
Beklenen Yaşam Süresi $\left(\mathrm{K}_{5}\right)$ & 7 & $\mathrm{~K}_{3}$ & 0,05 & 1,050 & 0,750 & 0,119 \\
Bebek Ölüm Oranları $\left(\mathrm{K}_{6}\right)$ & 1 & $\mathrm{~K}_{7}$ & 0,05 & 1,050 & 0,714 & 0,114 \\
Tıbbi Teknoloji $\left(\mathrm{K}_{7}\right)$ & 6 & $\mathrm{~K}_{5}$ & 0,05 & 1,050 & 0,680 & 0,108 \\
Tıp Mezunları $\left(\mathrm{K}_{8}\right)$ & 8 & $\mathrm{~K}_{8}$ & 0,10 & 1,100 & 0,618 & 0,098 \\
\hline
\end{tabular}

Diğer karar vericiler için de Tablo 4'te görülen hesaplamalar yapılarak her karar vericiye ait kriter ağırlıkları hesaplanmış ve bu değerler Tablo 5’te verilmiştir.

Tablo 5. Karar Vericiler Tarafından Hesaplanan Kriter Ağırlıkları

\begin{tabular}{lccccccc}
\hline Kriterler & $\mathbf{K V}_{\mathbf{1}}$ & $\mathbf{K V}_{\mathbf{2}}$ & $\mathbf{K V}_{\mathbf{3}}$ & $\mathbf{K V}_{\mathbf{4}}$ & $\mathbf{K V}_{\mathbf{5}}$ & $\mathbf{K V}_{\mathbf{6}}$ & $\begin{array}{c}\mathbf{G E O} \\
\mathbf{O R T}\end{array}$ \\
\hline Sağlık Harcamaları $\left(\mathrm{K}_{1}\right)$ & 0,145 & 0,144 & 0,13 & 0,150 & 0,138 & 0,115 & 0,135 \\
Hastane yatak sayısı $\left(\mathrm{K}_{2}\right)$ & 0,132 & 0,113 & 0,11 & 0,12 & 0,108 & 0,121 & 0,116 \\
Doktor Sayısı $\left(\mathrm{K}_{3}\right)$ & 0,119 & 0,151 & 0,14 & 0,14 & 0,131 & 0,14 & 0,137 \\
Hemşire Sayısı $\left(\mathrm{K}_{4}\right)$ & 0,125 & 0,119 & 0,11 & 0,12 & 0,119 & 0,127 & 0,121 \\
Beklenen Yaşam Süresi $\left(\mathrm{K}_{5}\right)$ & 0,108 & 0,125 & 0,12 & 0,1 & 0,145 & 0,147 & 0,123 \\
Bebek Ölüm Oranları $\left(\mathrm{K}_{6}\right)$ & 0,159 & 0,137 & 0,15 & 0,17 & 0,152 & 0,154 & 0,153 \\
Tıbbi Teknoloji $\left(\mathrm{K}_{7}\right)$ & 0,114 & 0,103 & 0,14 & 0,11 & 0,114 & 0,105 & 0,114 \\
Tıp Mezunları $\left(\mathrm{K}_{8}\right)$ & 0,098 & 0,108 & 0,10 & 0,09 & 0,094 & 0,091 & 0,098 \\
\hline
\end{tabular}

Her bir kriter için altı karar verici tarafindan hesaplanarak belirlenen değerlerin bütünleştirme işlemi geometrik ortalamaları alınarak yapılmıştır. Literatürde yer alan çalışmalar incelendiğinde bütünleştirme 
işlemi aşamasında geometrik ortalamanın sıklıkla kullanıldığı görülmüştür. Bu nedenle bu çalışmada da geometrik ortalamadan yararlanılmış ve Tablo 6'da gösterildiği üzere kriterlerin nihai ağırlıklarına ulaşılmıştır.

Tablo 6. Kriterlerin Ağırlıkları

\begin{tabular}{lc}
\hline Kriterler & Kriter Ağırlıkları \\
\hline Sağlık Harcamaları $\left(\mathrm{K}_{1}\right)$ & 0,135 \\
Hastane yatak sayısı $\left(\mathrm{K}_{2}\right)$ & 0,116 \\
Doktor Sayısı $\left(\mathrm{K}_{3}\right)$ & 0,137 \\
Hemşire Sayısı $\left(\mathrm{K}_{4}\right)$ & 0,121 \\
Beklenen Yaşam Süresi $\left(\mathrm{K}_{5}\right)$ & 0,123 \\
Bebek Ölüm Oranları $\left(\mathrm{K}_{6}\right)$ & 0,153 \\
T1bbi Teknoloji $\left(\mathrm{K}_{7}\right)$ & 0,114 \\
Tıp Mezunları $\left(\mathrm{K}_{8}\right)$ & 0,098 \\
\hline
\end{tabular}

SWARA yöntemiyle elde edilen sonuçlara göre en önemli kriter 0,153 değeriyle "Bebek Ölüm Oranları $\left(\mathrm{K}_{6}\right)$ " olarak belirlenmiştir. Onu sırasıyla "Doktor Sayısı $\left(\mathrm{K}_{3}\right)$, Sağlık Harcamaları $\left(\mathrm{K}_{1}\right)$, Beklenen Yaşam Süresi $\left(\mathrm{K}_{5}\right)$, Hemşire Sayısı $\left(\mathrm{K}_{4}\right)$, Hastane Yatak Sayısı $\left(\mathrm{K}_{2}\right)$, Tıbbi Teknoloji $\left(\mathrm{K}_{7}\right)$ ve Tıp Mezunları $\left(\mathrm{K}_{8}\right) "$ izlemektedir.

\subsection{WASPAS Yöntemi ile OECD Ülkelerinin Sıralanması}

WASPAS yönteminin ilk adımında karar matrisi oluşturulmuş ve Tablo 7'de gösterilmiştir. Bu matriste, kullanılan veriler güncel olup OECD ve Dünya Sağlık Örgütü (WHO) kaynaklarından faydalanılarak elde edilmiştir ${ }^{2}$.

Tablo 7. Karar Matrisi

\begin{tabular}{lcccccccc}
\hline & Maks & Maks & Maks & Maks & Maks & Min & Maks & Maks \\
\hline Ülkeler & $\mathbf{K}_{\mathbf{1}}$ & $\mathbf{K}_{\mathbf{2}}$ & $\mathbf{K}_{\mathbf{3}}$ & $\mathbf{K}_{\mathbf{4}}$ & $\mathbf{K}_{\mathbf{5}}$ & $\mathbf{K}_{\mathbf{6}}$ & $\mathbf{K}_{\mathbf{7}}$ & $\mathbf{K}_{\mathbf{8}}$ \\
\hline $\boldsymbol{w}_{\boldsymbol{j}}$ & 0,135 & 0,116 & 0,137 & 0,121 & 0,123 & 0,153 & 0,114 & 0,098 \\
\hline Avustralya & 9,133 & 3,810 & 3,570 & 11,640 & 82,50 & 3,100 & 4,03 & 15,940 \\
Avusturya & 10,321 & 7,420 & 5,130 & 7,990 & 81,70 & 3,100 & 5,41 & 14,090 \\
Belçika & 10,020 & 5,680 & 3,070 & 11,130 & 81,50 & 3,200 & 8,28 & 14,830 \\
Kanada & 10,411 & 2,550 & 2,720 & 9,910 & 81,90 & 4,700 & 8,07 & 7,940 \\
Şili & 8,091 & 2,120 & 1,026 & 5,600 & 79,90 & 6,900 & 0,91 & 8,690 \\
Çek Cum & 7,115 & 6,850 & 3,690 & 8,070 & 79,10 & 2,800 & 4,86 & 12,660 \\
Danimarka & 10,218 & 2,160 & 3,680 & 16,900 & 80,90 & 3,100 & 9,61 & 22,060 \\
Estonya & 6,719 & 4,760 & 3,460 & 6,100 & 77,80 & 2,300 & 2,33 & 11,480 \\
Finlandiya & 9,227 & 3,970 & 3,210 & 14,260 & 81,50 & 1,900 & 7,37 & 12,030 \\
Fransa & 11,458 & 6,050 & 3,350 & 10,190 & 82,40 & 3,700 & 7,51 & 9,050 \\
Almanya & 11,272 & 8,060 & 4,190 & 12,850 & 81,10 & 3,400 & 6,44 & 11,710 \\
Yunanistan & 8,366 & 4,200 & 6,167 & 3,250 & 81,50 & 4,200 & 4,31 & 9,320 \\
Macaristan & 7,218 & 7,000 & 3,210 & 6,440 & 76,20 & 3,900 & 1,81 & 14,140 \\
İlanda & 8,486 & 3,110 & 3,930 & 14,710 & 82,30 & 0,700 & 6,07 & 15,800 \\
İrlanda & 7,095 & 2,990 & 3,070 & 11,610 & 81,80 & 3,000 & 3,89 & 24,440 \\
İsrail & 7,372 & 3,020 & 3,080 & 4,990 & 82,50 & 3,100 & 3,36 & 6,760 \\
İtalya & 8,901 & 3,200 & 4,010 & 6,540 & 83,30 & 2,800 & 6,41 & 12,350 \\
Japonya & 10,745 & 13,110 & 2,430 & 11,340 & 84,10 & 2,000 & 7,17 & 6,840 \\
Kore & 7,569 & 11,980 & 2,340 & 6,910 & 82,40 & 2,800 & 3,00 & 7,650 \\
Letonya & 6,269 & 5,720 & 3,210 & 4,640 & 74,70 & 3,700 & 5,37 & 17,280 \\
Litvanya & 6,313 & 6,690 & 4,470 & 7,700 & 74,80 & 4,500 & 3,65 & 16,110 \\
Lüksemburg & 6,079 & 4,640 & 2,960 & 11,720 & 82,80 & 3,800 & 3,77 & 0,000
\end{tabular}

${ }^{2}$ https://data.oecd.org/health.htm ( 31.10.2018).

https://www.who.int/gho/countries/en/ (31.10.2018). 


\begin{tabular}{lcccccccc} 
Meksika & 5,404 & 1,520 & 2,360 & 2,890 & 75,40 & 12,100 & 0,54 & 12,620 \\
Hollanda & 10,143 & 3,630 & 3,310 & 12,230 & 81,60 & 3,500 & 7,22 & 14,360 \\
Yeni Zelanda & 9,001 & 2,710 & 3,000 & 10,170 & 81,70 & 5,700 & 6,21 & 9,120 \\
Norveç & 10,369 & 3,690 & 4,680 & 17,730 & 82,50 & 2,200 & 8,13 & 11,140 \\
Polonya & 6,675 & 6,640 & 2,420 & 5,160 & 78,00 & 4,000 & 2,72 & 10,490 \\
Portekiz & 8,985 & 3,420 & 3,868 & 6,470 & 81,20 & 3,200 & 4,05 & 16,440 \\
Slovakya & 7,060 & 5,780 & 3,470 & 5,740 & 77,30 & 5,400 & 4,77 & 13,510 \\
Slovenya & 8,285 & 4,490 & 3,010 & 9,650 & 81,30 & 2,000 & 5,79 & 15,880 \\
İspanya & 8,841 & 2,970 & 3,820 & 5,510 & 83,40 & 2,700 & 4,16 & 13,390 \\
İsveç & 10,916 & 2,340 & 4,270 & 11,060 & 82,40 & 2,500 & 6,90 & 10,160 \\
İsviçre & 12,259 & 4,550 & 4,250 & 17,020 & 83,70 & 3,600 & 9,79 & 10,570 \\
Türkiye & 4,227 & 2,750 & 1,830 & 1,930 & 78,00 & 10,000 & 2,03 & 9,900 \\
İngiltere & 9,687 & 2,580 & 2,820 & 7,860 & 81,20 & 3,800 & 5,04 & 12,870 \\
ABD & 17,150 & 2,800 & 2,580 & 11,610 & 78,60 & 5,900 & 12,37 & 7,550 \\
\hline
\end{tabular}

İkinci adımda, her bir kriterin fayda veya maliyet cinsinden oluşuna göre normalizasyon işlemi gerçekleştirilirken Eşitlik (5) ve (6) 'dan yararlanılmıştır. Üçüncü adımda, Ağırlıklı Toplam Modeline (WSM) dayalı olarak her bir alternatifin toplam göreli önemleri Eşitlik (7) ile hesaplanmıştır. Hesaplama yapılırken, daha önce SWARA yöntemiyle belirlenen kriter ağırlıkları ile normalizasyon işlemi yapıldıktan sonra oluşturulan karar matrisindeki her bir alternatif değeri çapılmıştır. Daha sonra her bir alternatifin diğer kriterlerdeki değerleri toplanmış ve Tablo 8 'de yer alan $Q^{(1)}$ değerleri belirlenmiştir.

Tablo 8. Ağırlıkı Toplam Yöntemi (WSM) ile Toplam Göreli Önemlerinin Hesaplanması

\begin{tabular}{|c|c|c|c|c|c|c|c|c|c|}
\hline WSM & $\mathbf{K}_{1}$ & $\mathbf{K}_{2}$ & $\mathbf{K}_{3}$ & $\mathbf{K}_{4}$ & $\mathbf{K}_{5}$ & $\mathbf{K}_{6}$ & $\mathbf{K}_{7}$ & $\mathbf{K}_{8}$ & $\begin{array}{c}\text { Toplam } \\
\mathbf{Q}^{(\mathbf{1})} \\
\end{array}$ \\
\hline Avustralya & 0,072 & 0,034 & 0,079 & 0,079 & 0,121 & 0,035 & 0,037 & 0,064 & 0,521 \\
\hline Avusturya & 0,081 & 0,066 & 0,114 & 0,055 & 0,119 & 0,035 & 0,050 & 0,056 & 0,576 \\
\hline Belçika & 0,079 & 0,050 & 0,068 & 0,076 & 0,119 & 0,033 & 0,076 & 0,059 & 0,562 \\
\hline Kanada & 0,082 & 0,023 & 0,060 & 0,068 & 0,120 & 0,023 & 0,074 & 0,032 & 0,481 \\
\hline Şili & 0,064 & 0,019 & 0,023 & 0,038 & 0,117 & 0,016 & 0,008 & 0,035 & 0,319 \\
\hline Çek Cum & 0,056 & 0,061 & 0,082 & 0,055 & 0,116 & 0,038 & 0,045 & 0,051 & 0,503 \\
\hline Danimarka & 0,080 & 0,019 & 0,082 & 0,115 & 0,118 & 0,035 & 0,089 & 0,088 & 0,627 \\
\hline Estonya & 0,053 & 0,042 & 0,077 & 0,042 & 0,114 & 0,047 & 0,021 & 0,046 & 0,441 \\
\hline Finlandiya & 0,073 & 0,035 & 0,071 & 0,097 & 0,119 & 0,056 & 0,068 & 0,048 & 0,568 \\
\hline Fransa & 0,090 & 0,054 & 0,074 & 0,070 & 0,121 & 0,029 & 0,069 & 0,036 & 0,543 \\
\hline Almanya & 0,089 & 0,071 & 0,093 & 0,088 & 0,119 & 0,032 & 0,059 & 0,047 & 0,597 \\
\hline Yunanistan & 0,066 & 0,037 & 0,137 & 0,022 & 0,119 & 0,026 & 0,040 & 0,037 & 0,484 \\
\hline Macaristan & 0,057 & 0,062 & 0,071 & 0,044 & 0,111 & 0,027 & 0,017 & 0,057 & 0,446 \\
\hline İzlanda & 0,067 & 0,028 & 0,087 & 0,100 & 0,120 & 0,153 & 0,056 & 0,063 & 0,675 \\
\hline İrlanda & 0,056 & 0,026 & 0,068 & 0,079 & 0,120 & 0,036 & 0,036 & 0,098 & 0,519 \\
\hline İsrail & 0,058 & 0,027 & 0,068 & 0,034 & 0,121 & 0,035 & 0,031 & 0,027 & 0,401 \\
\hline İtalya & 0,070 & 0,028 & 0,089 & 0,045 & 0,122 & 0,038 & 0,059 & 0,050 & 0,501 \\
\hline Japonya & 0,085 & 0,116 & 0,054 & 0,077 & 0,123 & 0,054 & 0,066 & 0,027 & 0,602 \\
\hline Kore & 0,060 & 0,106 & 0,052 & 0,047 & 0,121 & 0,038 & 0,028 & 0,031 & 0,482 \\
\hline Letonya & 0,049 & 0,051 & 0,071 & 0,032 & 0,109 & 0,029 & 0,049 & 0,069 & 0,460 \\
\hline Litvanya & 0,050 & 0,059 & 0,099 & 0,053 & 0,109 & 0,024 & 0,034 & 0,065 & 0,492 \\
\hline Lüksemburg & 0,048 & 0,041 & 0,066 & 0,080 & 0,121 & 0,028 & 0,035 & 0,000 & 0,419 \\
\hline Meksika & 0,043 & 0,013 & 0,052 & 0,020 & 0,110 & 0,009 & 0,005 & 0,051 & 0,303 \\
\hline Hollanda & 0,080 & 0,032 & 0,074 & 0,083 & 0,119 & 0,031 & 0,067 & 0,058 & 0,543 \\
\hline Yeni Zelanda & 0,071 & 0,024 & 0,067 & 0,069 & 0,119 & 0,019 & 0,057 & 0,037 & 0,463 \\
\hline Norveç & 0,082 & 0,033 & 0,104 & 0,121 & 0,121 & 0,049 & 0,075 & 0,045 & 0,628 \\
\hline
\end{tabular}




\begin{tabular}{llllllllll} 
Polonya & 0,053 & 0,059 & 0,054 & 0,035 & 0,114 & 0,027 & 0,025 & 0,042 & 0,408 \\
Portekiz & 0,071 & 0,030 & 0,086 & 0,044 & 0,119 & 0,033 & 0,037 & 0,066 & 0,487 \\
Slovakya & 0,056 & 0,051 & 0,077 & 0,039 & 0,113 & 0,020 & 0,044 & 0,054 & 0,454 \\
Slovenya & 0,065 & 0,040 & 0,067 & 0,066 & 0,119 & 0,054 & 0,053 & 0,064 & 0,527 \\
İspanya & 0,070 & 0,026 & 0,085 & 0,038 & 0,122 & 0,040 & 0,038 & 0,054 & 0,472 \\
İsvec & 0,086 & 0,021 & 0,095 & 0,075 & 0,121 & 0,043 & 0,064 & 0,041 & 0,545 \\
İsviçre & 0,096 & 0,040 & 0,094 & 0,116 & 0,122 & 0,030 & 0,090 & 0,042 & 0,632 \\
Türkiye & 0,033 & 0,024 & 0,041 & 0,013 & 0,114 & 0,011 & 0,019 & 0,040 & 0,295 \\
İngiltere & 0,076 & 0,023 & 0,063 & 0,054 & 0,119 & 0,028 & 0,046 & 0,052 & 0,460 \\
ABD & 0,135 & 0,025 & 0,057 & 0,079 & 0,115 & 0,018 & 0,114 & 0,030 & 0,574 \\
\hline
\end{tabular}

Dördüncü adımda ise, Ağırlıklandırılmış Çarpım Modeli (WPM) kullanılarak ikinci toplam göreceli önem değeri olan $Q^{(2)}$ Eşitlik (8) yardımıyla hesaplanmıştır ve Tablo 9'da gösterilmiştir.

Tablo 9. Ağırıklı Çapım Yöntemi (WPM) ile Toplam Göreli Önemlerinin Hesaplanması

\begin{tabular}{|c|c|c|c|c|c|c|c|c|c|}
\hline WPM & $\mathbf{K}_{1}$ & $\mathbf{K}_{2}$ & $\mathbf{K}_{3}$ & $\mathbf{K}_{4}$ & $\mathbf{K}_{5}$ & $\mathbf{K}_{6}$ & $\mathbf{K}_{7}$ & $\mathbf{K}_{8}$ & $\begin{array}{c}\text { Toplam } \\
\mathbf{Q}^{(2)} \\
\end{array}$ \\
\hline Avustralya & 0,918 & 0,866 & 0,928 & 0,950 & 0,998 & 0,796 & 0,880 & 0,959 & 0,470 \\
\hline Avusturya & 0,934 & 0,936 & 0,975 & 0,908 & 0,996 & 0,796 & 0,910 & 0,947 & 0,530 \\
\hline Belçika & 0,930 & 0,908 & 0,909 & 0,945 & 0,996 & 0,793 & 0,955 & 0,952 & 0,521 \\
\hline Kanada & 0,935 & 0,827 & 0,894 & 0,932 & 0,997 & 0,747 & 0,952 & 0,896 & 0,409 \\
\hline Şili & 0,904 & 0,809 & 0,782 & 0,870 & 0,994 & 0,705 & 0,743 & 0,904 & 0,234 \\
\hline Çek Cum & 0,888 & 0,927 & 0,932 & 0,909 & 0,992 & 0,809 & 0,899 & 0,938 & 0,472 \\
\hline Danimarka & 0,932 & 0,811 & 0,932 & 0,994 & 0,995 & 0,796 & 0,972 & 0,990 & 0,534 \\
\hline Estonya & 0,881 & 0,889 & 0,924 & 0,879 & 0,990 & 0,834 & 0,827 & 0,929 & 0,403 \\
\hline Finlandiya & 0,920 & 0,871 & 0,914 & 0,974 & 0,996 & 0,858 & 0,943 & 0,933 & 0,536 \\
\hline Fransa & 0,947 & 0,914 & 0,920 & 0,935 & 0,997 & 0,775 & 0,945 & 0,907 & 0,493 \\
\hline Almanya & 0,945 & 0,945 & 0,948 & 0,962 & 0,996 & 0,785 & 0,928 & 0,930 & 0,550 \\
\hline Yunanistan & 0,908 & 0,876 & 1,000 & 0,814 & 0,996 & 0,760 & 0,887 & 0,910 & 0,396 \\
\hline Macaristan & 0,890 & 0,930 & 0,914 & 0,885 & 0,988 & 0,769 & 0,803 & 0,948 & 0,387 \\
\hline İzlanda & 0,909 & 0,846 & 0,940 & 0,978 & 0,997 & 1,000 & 0,922 & 0,958 & 0,623 \\
\hline İrlanda & 0,888 & 0,842 & 0,909 & 0,950 & 0,997 & 0,800 & 0,876 & 1,000 & 0,451 \\
\hline İsrail & 0,892 & 0,843 & 0,909 & 0,858 & 0,998 & 0,796 & 0,862 & 0,882 & 0,354 \\
\hline İtalya & 0,915 & 0,849 & 0,943 & 0,886 & 0,999 & 0,809 & 0,928 & 0,935 & 0,455 \\
\hline Japonya & 0,939 & 1,000 & 0,880 & 0,947 & 1,000 & 0,852 & 0,940 & 0,883 & 0,553 \\
\hline Kore & 0,895 & 0,990 & 0,876 & 0,892 & 0,997 & 0,809 & 0,851 & 0,892 & 0,424 \\
\hline Letonya & 0,873 & 0,908 & 0,914 & 0,850 & 0,986 & 0,775 & 0,909 & 0,967 & 0,414 \\
\hline Litvanya & 0,874 & 0,925 & 0,957 & 0,904 & 0,986 & 0,752 & 0,870 & 0,960 & 0,433 \\
\hline Lüksemburg & 0,869 & 0,886 & 0,904 & 0,951 & 0,998 & 0,772 & 0,873 & 0,000 & 0,000 \\
\hline Meksika & 0,856 & 0,779 & 0,877 & 0,803 & 0,987 & 0,647 & 0,700 & 0,937 & 0,196 \\
\hline Hollanda & 0,932 & 0,862 & 0,918 & 0,956 & 0,996 & 0,782 & 0,940 & 0,949 & 0,490 \\
\hline Yeni Zelanda & 0,917 & 0,833 & 0,906 & 0,935 & 0,996 & 0,726 & 0,924 & 0,908 & 0,392 \\
\hline Norveç & 0,934 & 0,863 & 0,963 & 1,000 & 0,998 & 0,839 & 0,953 & 0,926 & 0,574 \\
\hline Polonya & 0,880 & 0,924 & 0,880 & 0,861 & 0,991 & 0,766 & 0,841 & 0,920 & 0,362 \\
\hline Portekiz & 0,916 & 0,856 & 0,938 & 0,885 & 0,996 & 0,793 & 0,880 & 0,962 & 0,435 \\
\hline Slovakya & 0,887 & 0,909 & 0,924 & 0,872 & 0,990 & 0,732 & 0,897 & 0,944 & 0,399 \\
\hline Slovenya & 0,906 & 0,883 & 0,906 & 0,929 & 0,996 & 0,852 & 0,917 & 0,959 & 0,503 \\
\hline İspanya & 0,914 & 0,842 & 0,936 & 0,868 & 0,999 & 0,813 & 0,883 & 0,943 & 0,423 \\
\hline İsveç & 0,941 & 0,819 & 0,951 & 0,944 & 0,997 & 0,823 & 0,936 & 0,918 & 0,488 \\
\hline
\end{tabular}




\begin{tabular}{llllllllll} 
İsviçre & 0,956 & 0,884 & 0,950 & 0,995 & 0,999 & 0,778 & 0,974 & 0,921 & 0,558 \\
Türkiye & 0,828 & 0,834 & 0,847 & 0,765 & 0,991 & 0,666 & 0,814 & 0,915 & 0,220 \\
İngiltere & 0,926 & 0,828 & 0,898 & 0,906 & 0,996 & 0,772 & 0,903 & 0,939 & 0,407 \\
ABD & 1,000 & 0,836 & 0,887 & 0,950 & 0,992 & 0,722 & 1,000 & 0,891 & 0,450 \\
\hline
\end{tabular}

Beşinci adımda $\lambda$ değeri 0,5 olarak alınmıştır. Alternatiflerin toplam göreli $\left(Q_{i}\right)$ önemi Eşitlik (9) ile hesaplanmış ve Tablo 10'da ülkelerin performans sıralama sonuçları gösterilmiştir.

Tablo 10. WASPAS Yöntemi Kullanılarak Elde Edilen Sonuçlar

\begin{tabular}{|c|c|c|c|c|}
\hline Ülkeler & WSM & WPM & $Q i$ & Siralama \\
\hline Avustralya & 0,521 & 0,470 & 0,496 & 15 \\
\hline Avusturya & 0,576 & 0,530 & 0,553 & 7 \\
\hline Belçika & 0,562 & 0,521 & 0,541 & 9 \\
\hline Kanada & 0,481 & 0,409 & 0,445 & 23 \\
\hline Şili & 0,319 & 0,234 & 0,276 & 33 \\
\hline Çek Cum & 0,503 & 0,472 & 0,488 & 16 \\
\hline Danimarka & 0,627 & 0,534 & 0,580 & 4 \\
\hline Estonya & 0,441 & 0,403 & 0,422 & 29 \\
\hline Finlandiya & 0,568 & 0,536 & 0,552 & 8 \\
\hline Fransa & 0,543 & 0,493 & 0,518 & 10 \\
\hline Almanya & 0,597 & 0,550 & 0,574 & 6 \\
\hline Yunanistan & 0,484 & 0,396 & 0,440 & 24 \\
\hline Macaristan & 0,446 & 0,387 & 0,417 & 30 \\
\hline İzlanda & 0,675 & 0,623 & 0,649 & 1 \\
\hline İrlanda & 0,519 & 0,451 & 0,485 & 17 \\
\hline İsrail & 0,401 & 0,354 & 0,377 & 32 \\
\hline İtalya & 0,501 & 0,455 & 0,478 & 18 \\
\hline Japonya & 0,602 & 0,553 & 0,578 & 5 \\
\hline Kore & 0,482 & 0,424 & 0,453 & 21 \\
\hline Letonya & 0,460 & 0,414 & 0,437 & 25 \\
\hline Litvanya & 0,492 & 0,433 & 0,463 & 19 \\
\hline Lüksemburg & 0,419 & 0,000 & 0,209 & 36 \\
\hline Meksika & 0,303 & 0,196 & 0,250 & 35 \\
\hline Hollanda & 0,543 & 0,490 & 0,516 & 11 \\
\hline Yeni Zelanda & 0,463 & 0,392 & 0,428 & 27 \\
\hline Norveç & 0,628 & 0,574 & 0,601 & 2 \\
\hline Polonya & 0,408 & 0,362 & 0,385 & 31 \\
\hline Portekiz & 0,487 & 0,435 & 0,461 & 20 \\
\hline Slovakya & 0,454 & 0,399 & 0,426 & 28 \\
\hline Slovenya & 0,527 & 0,503 & 0,515 & 13 \\
\hline İspanya & 0,472 & 0,423 & 0,448 & 22 \\
\hline İsveç & 0,545 & 0,488 & 0,516 & 12 \\
\hline İsviçre & 0,632 & 0,558 & 0,595 & 3 \\
\hline Türkiye & 0,295 & 0,220 & 0,257 & 34 \\
\hline İngiltere & 0,460 & 0,407 & 0,434 & 26 \\
\hline ABD & 0,574 & 0,450 & 0,512 & 14 \\
\hline
\end{tabular}

Bu sonuçlara göre ilk üç sırada yer almakta olan ülkeler İzlanda, Norveç ve İsviçre olmuş ve son üç sırada yer almakta olan ülkeler ise Türkiye, Meksika ve Lüksemburg olarak belirlenmiştir. 


\subsection{CODAS Yöntemi ile OECD Ülkelerinin Sıralanması}

İlk olarak Tablo 7'de gösterilen karar matrisinde faydalı kriterler için maksimum değerler, maliyet kriteri için minimum değerler belirlenmiştir. İkinci adımda, Eşitlik (10) yardımıyla kriterlerin fayda ya da maliyet kriteri oluşuna göre normalizasyon işlemi yapılmıştır. Tablo 11 'de normalizasyon işlemi sonrası oluşturulan değerler gösterilmiştir.

Tablo 11. Normalize Edilmiș Karar Matrisi

\begin{tabular}{|c|c|c|c|c|c|c|c|c|}
\hline Ülkeler & $\mathbf{K}_{1}$ & $\mathbf{K}_{\mathbf{2}}$ & $\mathbf{K}_{3}$ & $\mathbf{K}_{4}$ & $\mathbf{K}_{5}$ & $K_{6}$ & $\mathbf{K}_{7}$ & $\mathrm{~K}_{8}$ \\
\hline Avustralya & 0,533 & 0,291 & 0,579 & 0,657 & 0,981 & 0,226 & 0,326 & 0,652 \\
\hline Avusturya & 0,602 & 0,566 & 0,832 & 0,451 & 0,971 & 0,226 & 0,437 & 0,577 \\
\hline Belçika & 0,584 & 0,433 & 0,498 & 0,628 & 0,969 & 0,219 & 0,669 & 0,607 \\
\hline Kanada & 0,607 & 0,195 & 0,441 & 0,559 & 0,974 & 0,149 & 0,652 & 0,325 \\
\hline Şili & 0,472 & 0,162 & 0,166 & 0,316 & 0,950 & 0,101 & 0,074 & 0,356 \\
\hline Çek Cum & 0,415 & 0,523 & 0,598 & 0,455 & 0,941 & 0,250 & 0,393 & 0,518 \\
\hline Danimarka & 0,596 & 0,165 & 0,597 & 0,953 & 0,962 & 0,226 & 0,777 & 0,903 \\
\hline Estonya & 0,392 & 0,363 & 0,561 & 0,344 & 0,925 & 0,304 & 0,188 & 0,470 \\
\hline Finlandiya & 0,538 & 0,303 & 0,521 & 0,804 & 0,969 & 0,368 & 0,596 & 0,492 \\
\hline Fransa & 0,668 & 0,461 & 0,543 & 0,575 & 0,980 & 0,189 & 0,607 & 0,370 \\
\hline Almanya & 0,657 & 0,615 & 0,679 & 0,725 & 0,964 & 0,206 & 0,521 & 0,479 \\
\hline Yunanistan & 0,488 & 0,320 & 1,000 & 0,183 & 0,969 & 0,167 & 0,348 & 0,381 \\
\hline Macaristan & 0,421 & 0,534 & 0,521 & 0,363 & 0,906 & 0,179 & 0,146 & 0,579 \\
\hline İzlanda & 0,495 & 0,237 & 0,637 & 0,830 & 0,979 & 1,000 & 0,491 & 0,646 \\
\hline İrlanda & 0,414 & 0,228 & 0,498 & 0,655 & 0,973 & 0,233 & 0,314 & 1,000 \\
\hline İsrail & 0,430 & 0,230 & 0,499 & 0,281 & 0,981 & 0,226 & 0,272 & 0,277 \\
\hline İtalya & 0,519 & 0,244 & 0,650 & 0,369 & 0,990 & 0,250 & 0,518 & 0,505 \\
\hline Japonya & 0,627 & 1,000 & 0,394 & 0,640 & 1,000 & 0,350 & 0,580 & 0,280 \\
\hline Kore & 0,441 & 0,914 & 0,379 & 0,390 & 0,980 & 0,250 & 0,243 & 0,313 \\
\hline Letonya & 0,366 & 0,436 & 0,521 & 0,262 & 0,888 & 0,189 & 0,434 & 0,707 \\
\hline Litvanya & 0,368 & 0,510 & 0,725 & 0,434 & 0,889 & 0,156 & 0,295 & 0,659 \\
\hline Lüksemburg & 0,354 & 0,354 & 0,480 & 0,661 & 0,985 & 0,184 & 0,305 & 0,000 \\
\hline Meksika & 0,315 & 0,116 & 0,383 & 0,163 & 0,897 & 0,058 & 0,044 & 0,516 \\
\hline Hollanda & 0,591 & 0,277 & 0,537 & 0,690 & 0,970 & 0,200 & 0,584 & 0,588 \\
\hline Yeni Zelanda & 0,525 & 0,207 & 0,486 & 0,574 & 0,971 & 0,123 & 0,502 & 0,373 \\
\hline Norveç & 0,605 & 0,281 & 0,759 & 1,000 & 0,981 & 0,318 & 0,657 & 0,456 \\
\hline Polonya & 0,389 & 0,506 & 0,392 & 0,291 & 0,927 & 0,175 & 0,220 & 0,429 \\
\hline Portekiz & 0,524 & 0,261 & 0,627 & 0,365 & 0,966 & 0,219 & 0,327 & 0,673 \\
\hline Slovakya & 0,412 & 0,441 & 0,563 & 0,324 & 0,919 & 0,130 & 0,386 & 0,553 \\
\hline Slovenya & 0,483 & 0,342 & 0,488 & 0,544 & 0,967 & 0,350 & 0,468 & 0,650 \\
\hline İspanya & 0,516 & 0,227 & 0,619 & 0,311 & 0,992 & 0,259 & 0,336 & 0,548 \\
\hline İsveç & 0,637 & 0,178 & 0,692 & 0,624 & 0,980 & 0,280 & 0,558 & 0,416 \\
\hline İsviçre & 0,715 & 0,347 & 0,689 & 0,960 & 0,995 & 0,194 & 0,791 & 0,432 \\
\hline Türkiye & 0,246 & 0,210 & 0,297 & 0,109 & 0,927 & 0,070 & 0,164 & 0,405 \\
\hline İngiltere & 0,565 & 0,197 & 0,457 & 0,443 & 0,966 & 0,184 & 0,407 & 0,527 \\
\hline ABD & 1,000 & 0,214 & 0,418 & 0,655 & 0,935 & 0,119 & 1,000 & 0,309 \\
\hline
\end{tabular}

Üçüncü adımda, Tablo 5'te gösterilen kriterlerin ağırlıkları ve Tablo 11'deki normalize edilmiş değerler kullanılarak Eşitlik (11) yardımıyla, ağırlıklı normalleştirilmiş performans değerleri hesaplanmış ve Tablo 12 'de gösterilmiştir. 
Tablo 12. Ağırlıklı Normalleştirilmiş Karar Matrisi

\begin{tabular}{|c|c|c|c|c|c|c|c|c|c|c|}
\hline & $K_{1}$ & $\mathbf{K}_{2}$ & $\mathbf{K}_{3}$ & $\mathbf{K}_{4}$ & $\mathrm{~K}_{5}$ & $K_{6}$ & $\mathbf{K}_{7}$ & $\mathbf{K}_{8}$ & $E i$ & $T i$ \\
\hline Avustralya & 0,072 & 0,034 & 0,079 & 0,079 & 0,121 & 0,035 & 0,037 & 0,064 & 0,124 & 0,315 \\
\hline Avusturya & 0,081 & 0,066 & 0,114 & 0,055 & 0,119 & 0,035 & 0,050 & 0,056 & 0,145 & 0,370 \\
\hline Belçika & 0,079 & 0,050 & 0,068 & 0,076 & 0,119 & 0,033 & 0,076 & 0,059 & 0,137 & 0,356 \\
\hline Kanada & 0,082 & 0,023 & 0,060 & 0,068 & 0,120 & 0,023 & 0,074 & 0,032 & 0,114 & 0,276 \\
\hline Şili & 0,064 & 0,019 & 0,023 & 0,038 & 0,117 & 0,016 & 0,008 & 0,035 & 0,054 & 0,113 \\
\hline Çek Cum & 0,056 & 0,061 & 0,082 & 0,055 & 0,116 & 0,038 & 0,045 & 0,051 & 0,114 & 0,297 \\
\hline Danimarka & 0,080 & 0,019 & 0,082 & 0,115 & 0,118 & 0,035 & 0,089 & 0,088 & 0,178 & 0,421 \\
\hline Estonya & 0,053 & 0,042 & 0,077 & 0,042 & 0,114 & 0,047 & 0,021 & 0,046 & 0,094 & 0,236 \\
\hline Finlandiya & 0,073 & 0,035 & 0,071 & 0,097 & 0,119 & 0,056 & 0,068 & 0,048 & 0,142 & 0,362 \\
\hline Fransa & 0,090 & 0,054 & 0,074 & 0,070 & 0,121 & 0,029 & 0,069 & 0,036 & 0,129 & 0,337 \\
\hline Almanya & 0,089 & 0,071 & 0,093 & 0,088 & 0,119 & 0,032 & 0,059 & 0,047 & 0,151 & 0,391 \\
\hline Yunanistan & 0,066 & 0,037 & 0,137 & 0,022 & 0,119 & 0,026 & 0,040 & 0,037 & 0,133 & 0,278 \\
\hline Macaristan & 0,057 & 0,062 & 0,071 & 0,044 & 0,111 & 0,027 & 0,017 & 0,057 & 0,100 & 0,241 \\
\hline İzlanda & 0,067 & 0,028 & 0,087 & 0,100 & 0,120 & 0,153 & 0,056 & 0,063 & 0,202 & 0,469 \\
\hline İrlanda & 0,056 & 0,026 & 0,068 & 0,079 & 0,120 & 0,036 & 0,036 & 0,098 & 0,136 & 0,313 \\
\hline İsrail & 0,058 & 0,027 & 0,068 & 0,034 & 0,121 & 0,035 & 0,031 & 0,027 & 0,074 & 0,195 \\
\hline İtalya & 0,070 & 0,028 & 0,089 & 0,045 & 0,122 & 0,038 & 0,059 & 0,050 & 0,116 & 0,295 \\
\hline Japonya & 0,085 & 0,116 & 0,054 & 0,077 & 0,123 & 0,054 & 0,066 & 0,027 & 0,158 & 0,396 \\
\hline Kore & 0,060 & 0,106 & 0,052 & 0,047 & 0,121 & 0,038 & 0,028 & 0,031 & 0,117 & 0,276 \\
\hline Letonya & 0,049 & 0,051 & 0,071 & 0,032 & 0,109 & 0,029 & 0,049 & 0,069 & 0,107 & 0,254 \\
\hline Litvanya & 0,050 & 0,059 & 0,099 & 0,053 & 0,109 & 0,024 & 0,034 & 0,065 & 0,122 & 0,286 \\
\hline Lüksemburg & 0,048 & 0,041 & 0,066 & 0,080 & 0,121 & 0,028 & 0,035 & 0,000 & 0,093 & 0,213 \\
\hline Meksika & 0,043 & 0,013 & 0,052 & 0,020 & 0,110 & 0,009 & 0,005 & 0,051 & 0,060 & 0,097 \\
\hline Hollanda & 0,080 & 0,032 & 0,074 & 0,083 & 0,119 & 0,031 & 0,067 & 0,058 & 0,133 & 0,337 \\
\hline Yeni Zelanda & 0,071 & 0,024 & 0,067 & 0,069 & 0,119 & 0,019 & 0,057 & 0,037 & 0,104 & 0,257 \\
\hline Norveç & 0,082 & 0,033 & 0,104 & 0,121 & 0,121 & 0,049 & 0,075 & 0,045 & 0,172 & 0,422 \\
\hline Polonya & 0,053 & 0,059 & 0,054 & 0,035 & 0,114 & 0,027 & 0,025 & 0,042 & 0,080 & 0,202 \\
\hline Portekiz & 0,071 & 0,030 & 0,086 & 0,044 & 0,119 & 0,033 & 0,037 & 0,066 & 0,113 & 0,281 \\
\hline Slovakya & 0,056 & 0,051 & 0,077 & 0,039 & 0,113 & 0,020 & 0,044 & 0,054 & 0,101 & 0,248 \\
\hline Slovenya & 0,065 & 0,040 & 0,067 & 0,066 & 0,119 & 0,054 & 0,053 & 0,064 & 0,122 & 0,321 \\
\hline İspanya & 0,070 & 0,026 & 0,085 & 0,038 & 0,122 & 0,040 & 0,038 & 0,054 & 0,105 & 0,266 \\
\hline İsveç & 0,086 & 0,021 & 0,095 & 0,075 & 0,121 & 0,043 & 0,064 & 0,041 & 0,135 & 0,339 \\
\hline İsviçre & 0,096 & 0,040 & 0,094 & 0,116 & 0,122 & 0,030 & 0,090 & 0,042 & 0,174 & 0,426 \\
\hline Türkiye & 0,033 & 0,024 & 0,041 & 0,013 & 0,114 & 0,011 & 0,019 & 0,040 & 0,047 & 0,089 \\
\hline İngiltere & 0,076 & 0,023 & 0,063 & 0,054 & 0,119 & 0,028 & 0,046 & 0,052 & 0,100 & 0,255 \\
\hline ABD & 0,135 & 0,025 & 0,057 & 0,079 & 0,115 & 0,018 & 0,114 & 0,030 & 0,170 & 0,368 \\
\hline
\end{tabular}

Selçuk Üniversitesi Sosyal Bilimler Meslek Yüksekokulu Dergisi, Yıl: 2020 Cilt: 23 Sayı:1 
Tablo 12'de, ağırlıklı normalleştirilmiş karar matrisi ve bunlara karşılık gelen negatif-ideal çözümler gösterilmektedir. Ayrıca, bu tablonun son iki sütununda yer almakta olan negatif-ideal çözümden alternatiflerin Öklid ve Taxicab mesafeleri Eşitlik (14) ve (15) yardımıyla hesaplanmıştır. Göreceli değerlendirme matrisi $R a$ ve alternatiflerin değerlendirme puanları olan $H_{i}$ değerleri, Tablo 12 'deki değerler dikkate alınarak ve Eşitlik (16), (17), (18) ve (19) kullanılarak hesaplanmıştır. Hesaplamalarda $\tau$ değeri 0,02 olarak kabul edilmiştir. Elde edilen sıralamalar Tablo 13'te gösterilmiştir.

Tablo 13. CODAS Yöntemi ile Elde Edilen Sonuçlar

\begin{tabular}{lcclcc}
\hline Ülkeler & $\boldsymbol{H}_{\boldsymbol{i}}$ & Siralama & Ülkeler & $\boldsymbol{H}_{\boldsymbol{i}}$ & Sıralama \\
\hline Avustralya & 0,627 & 16 & Kore & $-0,494$ & 21 \\
Avusturya & 3,365 & 8 & Letonya & $-1,691$ & 25 \\
Belçika & 2,447 & 10 & Litvanya & 0,055 & 18 \\
Kanada & $-0,799$ & 22 & Lüksemburg & $-3,630$ & 31 \\
Şili & $-8,975$ & 34 & Meksika & $-9,204$ & 35 \\
Çek Cum & $-0,369$ & 20 & Hollanda & 1,732 & 12 \\
Danimarka & 6,558 & 2 & Yeni Zelanda & $-1,739$ & 26 \\
Estonya & $-3,046$ & 30 & Norveç & 6,359 & 4 \\
Finlandiya & 2,886 & 9 & Polonya & $-4,715$ & 32 \\
Fransa & 1,470 & 13 & Portekiz & $-0,906$ & 23 \\
Almanya & 4,156 & 7 & Slovakya & $-2,228$ & 28 \\
Yunanistan & 0,553 & 17 & Slovenya & 0,674 & 15 \\
Macaristan & $-2,483$ & 29 & İspanya & $-1,531$ & 24 \\
İzlanda & 9,180 & 1 & İsveç & 1,945 & 11 \\
İrlanda & 1,426 & 14 & İsviçre & 6,543 & 3 \\
İsrail & $-5,304$ & 33 & Türkiye & $-10,024$ & 36 \\
İtalya & $-0,324$ & 19 & İngiltere & $-2,104$ & 27 \\
Japonya & 4,955 & 5 & ABD & 4,634 & 6 \\
\hline
\end{tabular}

CODAS yöntemi ile oluşturulan sıralamalar sonucunda İzlanda, Danimarka, İsviçre ilk üç sırada yer alırken, Şili, Meksika ve Türkiye son sıralarda yer almaktadır.

\subsection{WASPAS ve CODAS Yöntemleri ile Elde Edilen Sıralamaların Karşılaştırılması}

Bu çalışmada WASPAS ve CODAS yöntemleri kullanılarak OECD ülkeleri sağlık göstergeleri açısından sıralanmıştır. Elde edilen sıralamalar Tablo 14’te gösterilmiştir.

Tablo 14. WASPAS ve CODAS Yöntemleriyle Oluşturulan Sıralamalar

\begin{tabular}{lcclcc}
\hline Ülkeler & WASPAS & CODAS & Ülkeler & WASPAS & CODAS \\
\hline Avustralya & 15 & 16 & Kore & 21 & 21 \\
Avusturya & 7 & 8 & Letonya & 25 & 25 \\
Belçika & 9 & 10 & Litvanya & 19 & 18 \\
Kanada & 23 & 22 & Lüksemburg & 36 & 31 \\
Şili & 33 & 34 & Meksika & 35 & 35 \\
Çek Cum & 16 & 20 & Hollanda & 11 & 12 \\
Danimarka & 4 & 2 & Yeni Zelanda & 27 & 26 \\
Estonya & 29 & 30 & Norveç & 2 & 4 \\
Finlandiya & 8 & 9 & Polonya & 31 & 32 \\
Fransa & 10 & 13 & Portekiz & 20 & 23 \\
Almanya & 6 & 7 & Slovakya & 28 & 28 \\
Yunanistan & 24 & 17 & Slovenya & 13 & 15 \\
Macaristan & 30 & 29 & İspanya & 22 & 24 \\
İzlanda & 1 & 1 & Isveç & 12 & 11 \\
İrlanda & 17 & 14 & İsviçre & 3 & 3 \\
İsrail & 32 & 33 & Türkiye & 34 & 36 \\
İtalya & 18 & 19 & İngiltere & 26 & 27 \\
Japonya & 5 & 5 & ABD & 14 & 6 \\
\hline
\end{tabular}

WASPAS ve CODAS yöntemleri sonucu elde edilen sıralamalar arasındaki ilişkiyi belirlemek için Spearman korelasyon katsayısından yararlanılmış ve 0,995 değeri elde edilmiştir. Elde edilen bu sonuca göre 
kullanılan yöntemler arasındaki ilişkinin 0,99 'un üzerinde olduğu ve birbiriyle uyum içerisinde bulunduğu görülmektedir.

\section{SONUÇ}

Sağlıklı şekilde birey yetiştiren toplumlar, refah ve gelişmişlik düzeyleri açısından iyi bir konuma sahiptir. Toplumlar için önemli olan güvenlik, güç, refah ve mutluluğunun temelinde bulunan, bireylerin ruhen ve bedenen sağlıklı olmasıdır. Bu nedenle sağlık alanında yapılan her türlü gelişme başta birey olmak üzere tüm toplumu etkileyebilecek şekildedir.

Bu çalışmada, OECD örgütüne üye 36 ülke, sağlık harcamalarının GSYİH'daki pay1,1000 kişi başına hastane yatak sayısı, 1000 kişi başına doktor sayısı, 1000 kişi başına hemşire sayısı, beklenen yaşam süresi, 1000 yeni doğan başına bebek ölüm oranı, tıbbi teknoloji, 100.000 kişi başına tıp mezunu kriterleri altında sıralanmıştır. İlk olarak SWARA yöntemi kullanılarak sekiz kriterin göreceli önem düzeyleri belirlenmiştir. En yüksek değere sahip olan kriter 0,153 ile "Bebek Ölüm Oranları $\left(\mathrm{K}_{6}\right)$ " olmuştur. Daha sonra "Doktor Sayıs1 $\left(\mathrm{K}_{3}\right)$, Sağlık Harcamaları $\left(\mathrm{K}_{1}\right)$, Beklenen Yaşam Süresi $\left(\mathrm{K}_{5}\right)$, Hemşire Sayısı $\left(\mathrm{K}_{4}\right)$, Hastane Yatak Sayısı $\left(\mathrm{K}_{2}\right)$, Tıbbi Teknoloji $\left(\mathrm{K}_{7}\right)$ ve Tıp Mezunları $\left(\mathrm{K}_{8}\right)^{\prime}$ s şeklinde sıralama devam etmiştir. Daha sonra, bu kriterler altında ülkelerin sıralamalarına WASPAS ve CODAS yöntemleri yardımıyla ulaşılmıştır. WASPAS yöntemi kullanıldığında, İzlanda, Norveç, İsviçre, Danimarka, Japonya ilk beş sıradayken, İsrail, Şili, Türkiye, Meksika, Lüksemburg son sıralarda olmuştur ve CODAS yöntemi ile elde edilen sıralamada İzlanda, Danimarka, İsviçre, Norveç ve Japonya ilk beş sırada, Polonya, İsrail, Şili, Meksika, Türkiye son sıralarda yer almıştır. Uygulama sonucunda kullanılan yöntemlerde ilk beş sırada yer almakta olan ülkelerin, kullanılan yönteme göre kendi içerisinde sıralama farklılıkları göstermesine rağmen aynı ülkeler olduğu tespit edilmiştir. Aynı şekilde son sıralarda yer almakta olan ülkeler de birbiriyle benzerlik göstermiştir. Yöntemler arasındaki ilişkileri belirlemek için hesaplanan Spearman korelasyon katsayısı katsayısı 0.995 olarak hesaplanmıştır. Elde edilen bu değer, kullanılan yöntemler arasındaki ilişkinin 0,99'un üzerinde olduğunu göstermektedir. Kullanılan yöntemlerin sağlık gösterge kriterleri altında ülkelerin sıralamasını belirlemek için etkin sonuçlar verdiği görülmüş̧ür.

Türkiye, bu çalışmada kullanılmış olan sağlık gösterge kriterleri altında değerlendirildiğinde son sıralarda yer almıştır. Türkiye ile birlikte son sıralarda yer almakta olan diğer bir ülke Meksika'nın özellikle bebek ölüm oranlarının diğer OECD ülke ortalamasından oldukça yüksek olduğu görülmektedir. Bebek ölüm oranları bir ülkedeki sağlık hizmetlerinin düzeyini, kalitesini temsil etmesi açısından oldukça önemli bir sağl1k göstergesidir. Bu nedenle bir ülkedeki bebek ölüm oranlarının fazla olması, diğer ölümlerin ve aynı zamanda sağlıklı nüfus kayıplarının yaşanacağı anlamını taşımaktadır. Beklenen yaşam süresinin uzunluğu ülkelerin ekonomik ve sosyal açıdan gelişmişliğini göstermektedir. Bu sürenin uzun olması o toplumlarda yaşayan insanların uzun yaşam beklentisiyle uzun vadeli yatırımlara yönelmesini sağlamakta ve böylelikle gelirlerde artış meydana getirmektedir. Sıralamada başlarda yer almakta olan Norveç, Danimarka, İsviçre, İzlanda, Japonya gibi ülkeler için beklenen yaşam süresinin uzun olduğu görülmektedir. Az gelişmiş ve gelişmekte olan toplumlarda bu sürenin daha düşük olduğu bilinmektedir. Elde edilen sıralamalarda son sıralarda yer alan Türkiye, Meksika, Polonya gibi ülkelerin beklenen yaşam süresinin, OECD ülke ortalamasının altında olduğu görülmektedir. Sıralamada sonlarda olan ülkelerdeki bireyler için beklenen yaşam süresinin arttırılması sağlık koşullarının iyileştirilmesiyle mümkündür. Bir ülke için sağlık harcama payının yüksek olması aynı zamanda ekonomik olarak da güçlü olabileceği anlamına gelmektedir. Siralama sonunda yer alan ülkelerin sağlık harcamalarını arttırması sağlık alanında yapılabilecek her türlü gelişme için önemlidir. Sıralamaya bakıldığında ilk sıralarda yer almakta olan ülkelerin sağlık harcamalarına ayırdığı payın yüksek olduğu görülmektedir. Türkiye başta olmak üzere diğer son sıralarda yer almakta olan ülkelerin sağl1k göstergelerinin iyileştirilmesi ve sağlık hizmetlerinin gelişmesi için doktor, hemşire gibi sağlık personel sayılarının arttırılması, hastane yataklarının, kullanılan tıbbi cihazların arttırılması gerekmektedir. Sağlık alanında yapılan harcamaların ve kaynakların arttırılması ile meydana gelecek diğer bir önemli gelişme temel sağlık hizmetlerinin iyileştirilmesi ve buna bağlı bebek ölüm oranlarının azalması olacaktır. Bu yüzden sıralamada sonlarda kalan ülkeler, özkaynağın büyük bir kısmını anne ve bebek sağlı̆̆ına ayırmalıdır. Okuryazar oranının düşük olduğu yerlerde, sağlık personelleri doğurgan yaşta olan kadınların bilinçlenmesine yönelik danışmanlık hizmeti vermeli, bilgilendirici seminerler düzenlemelidir. Aynı zamanda üniversitelerde sağlık alanındaki öğrenciler ve eğitim veren akademisyenler tarafından çeşitli sempozyumlar, paneller düzenlenip, projeler geliştirilerek bu alanda daha fazla bilinçlenme gerçekleştirilebilir.

Gelecek çalışmalarda, farklı sağlık gösterge kriterleri ve farklı ÇKKV yöntemleri kullanılarak ülkelerin sağlık alanındaki sıralamaları değerlendirilebilir. Ayrıca farklı kriter ağırlık belirleme yöntemlerinin ülkelerin sıralamasındaki etkisi araştırılabilir. 


\section{KAYNAKLAR}

Afonso A., Aubyn M., (2006). "Relative Efficiency of Health Provision: A DEA Approach With Non-Discretionary Inputs", Working Papers, Department of Economics At The School of Economics And Management (ISEG), Technical University of Lisbon.

Afonso, A., St. Aubyn, M. (2005) "Non-Parametric Approaches to Education and Health Efficiency in OECD Countries", Journal of Applied Economics 8(2), s.227-246.

Akçakanat Ö., Eren H., Aksoy E., Ömürbek V. (2017) "Bankacıllk Sektöründe ENTROPI ve WASPAS Yöntemleri ile Performans Değerlendirmesi", Süleyman Demirel Üniversitesi İktisadi ve İdari Bilimler Fakültesi Dergisi 22(2), s.285-300.

Alptekin, N. ve Yeşilaydın, G. (2015). "OECD Ülkelerinin Sağlık Göstergelerine Göre Bulanık Kümeleme Analizi İle Sınıflandırılması", İşletme Araştırmaları Dergisi (7)4, 137-155.

Aslan, Ş. Uyar, S. (2016) "Sağlık Hizmetleri Açısından Göstergelerin Önemi: Bozkır İlçesi Örneği", Uluslararası Sempozyum: Geçmişten Günümüze Bozkır, s.1129-1142.

Aytaç Adalı, E. (2016) "Personnel Selection in Health Sector with EVAMIX and TODIM Methods", Alphanumeric Journal 4(2), s.69-84.

Aytaç Adalı, E., Tuş Işıı, A. (2017) "Bir Tedarikçi Seçim Problemi için SWARA ve WASPAS Yöntemlerine Dayanan Karar Verme Yaklaşımı", International Review of Economics and Management 5(4), s.56-77.

Aytekin, A. (2016) "Hastaların Hastane Tercihinde Etkili Kriterler ve Hastanelerin MULTIMOORA ile Siralanması: Eskişehir Örneği", İşletme ve İktisat Çalışmaları Dergisi 4(4), s.134-143.

Ayyıldız, E., Demirci, E. (2018) "Türkiye'de Yer Alan Şehirlerin Yaşam Kalitelerinin SWARA Entegreli TOPSIS Yöntemi ile Belirlenmesi", Pamukkale Üniversitesi Sosyal Bilimler Enstitüsü Dergisi30, s.67-87.

Ayyıldız, E., Murat, M. (2017) "Türkiye'de Yer Alan Şehirlerin Eğitim Performanslarının Çok Kriterli Karar Verme Yöntemleri Kullanılarak Belirlenmesi", Kent Kültürü ve Yönetimi Hakemli Elektronik Dergi 10(2), s.255-267.

Badi, I.,Ballem, M., Shetwan, A. (2018) "Site Selection of Desalination Plant in Libya by Using Combinative DistanceBased Assessment (CODAS) Method", International JournalforQualityResearch12(3), 609-623.

Badi, I. A., Abdulshahed, A.M., Shetwan, A.G. (2017) "Supplier Selection Using Combinative Distance-Based Assessment (CODAS) Method for Multi-Criteria Decision-Making", The 1st International Conference on Management, Engineering and Environment, s.27-37.

Baušys, R., Juodagalvienè, B. (2017) "Garage Location Selection for Residential House by WASPAS-SVNS method", Journal of Civil Engineering and Management 23(3), s.421-429.

Boz, C., Önder, E. (2017) "OECD Ülkelerinin Sağlık Sistemi Performanslarının Değerlendirilmesi", Sosyal Güvence Dergisi 11, s.24-61.

Bulut, T., Durur, G. (2017) "Türkiye'nin Sağlık Turizm Performansının TOPSIS Yöntemiyle Değerlendirilmesi", Sağlık ve Sosyal Politikalara Bakış Dergisi 1,s.82-99.

Can, G.F., Delice, E.K., Cansu, B. (2017) "Çok Kriterli Karar Verme Yaklaşımıyla Oturma Düzeneği Seçimi", Mühendislik Bilimleri ve Tasarımı Dergisi 5, s.213-225.

Chakraborty, S., Bhattacharyya, O., Zavadskas, E.K., Antucheviciene, J. (2015) "Application of WASPAS Method as an Optimization Tool in Non-traditional Machining Processes", Information Technology and Control 44(1), s.77-88.

Chakraborty, S., Zavadskas, E.K. (2014) "Applications of WASPAS Method in Manufacturing Decision Making", Informatica 25(1), s.1-20.

Chu Ng, Y. 2008."The Productive Efficiency of The Health Care Sector of China," The Review of Regional Studies 38(3), s.381-393.

Cihan, Ş., Ayan, E., Eren, T., Topal, T., Yıldırım, E.K. (2017) "Çok Ölçütlü Karar Verme Yöntemleri ile Ekokardiyografi Cihazı Seçiminin Yapılması", HSP 4(1), s.41-49.

Çakır, E. (2017) "Kentsel Dönüşüm Kapsamında Müteahhit Firmanın SWARA- Gri İlişkisel Analiz Yöntemiyle Seçilmesi", Uluslararası Bilimsel Araştırmalar Dergisi 2(6), s.79-95.

Çakır, E. (2018) "Elektronik Belge Yönetim Sistemi (EBYS) Yazılımı Seçiminde Çok Kriterli Karar Verme Yöntemleri: Bir Belediye Örneği", Business, Economics and Management Research Journal- BEMAREJ1(1), s.15-30.

Çakır, E., Akar, G. S. (2017) " Bütünleşik TOPSIS ve SWARA Yöntemi ile Makine Seçimi: Bir Üretim İşletmesinde Uygulama", International Journal of Akademic Value Studies 3(13), s.206-216.

Çakır, E., Akel, G., Doğaner, M. (2018) "Türkiye'de Faaliyet Gösteren Özel Alışveriş Sitelerinin Bütünleşik SWARAWASPAS Yöntemi ile Değerlendirilmesi", UiiiiD-IJEAS 18, s.599-616.

Çakır, E., Karabıyık, K.B. (2017) "Bütünleşik SWARA-COPRAS Yöntemi Kullanarak Bulut Depolama Hizmet Sağlayıcılarının Değerlendirilmesi", Bilişim Teknolojileri Dergisi 10(4), s.417-434.

Ersöz F. (2009). "Türkiye ile OECD’ye Üye Ülkelerin Seçilmiş Sağlık Göstergelerinin Kümeleme ve Ayırma Analizi ile Karşılaştırılması", Türkiye Klinikleri Tıp Bilimleri Dergisi 29(6), 1650-1659.

Ghorshi Nezhad, M.R., Zolfani, S.H., Moztarzadeh, F., Zavadskas, E.K., Bahrami, M. (2015)."Planning the Priority of High Tech Industries based on SWARA-WASPAS Methodology: The Case of the Nano Technology in İran", Ekonomskaistrazivanja 28(1), s.1111-1137.

Girginer, N. (2013). "A Comparison of the Healthcare Indicators of Turkey and The European Union Members Countries Using Multidimensional Scaling Analysis and Cluster Analysis", İktisat İşletme ve Finans, 28(323), 55-72. 
Göztepe, B. H., (2017). "Çok Kriteli Karar Verme Yöntemlerini Kullanarak OECD'ye Üye Ülkelerin Sağlık Göstergeleri ile Değerlendirilmesi", Yüksek Lisans Tezi, Sosyal Bilimler Enstitüsü Ekonometri Anabilim Dalı, Antalya.

Gül, M., Çelik, E., Güneri, A.F., Gümüş, A.T. (2012) "Simülasyon ile Bütünleşik Çok Kriterli Karar Verme: Bir Hastane Acil Departmanı İçin Senaryo Seçimi Uygulaması", İstanbul Ticaret Üniversitesi Fen Bilimleri Dergisi 11(22), s.1-18.

Puig-Junoy, J . (1998) "Measuring Health Production Performance in the OECD", Applied Economics Letters 5(4), s.25559

Hajrahimi, N., Dehaghani, S., Sheikhtaheri, A. (2013) "Health Information Security: A Case Study of Three Selected Medical Centers in Iran", Acta Informatica Medica 21(1), s.42-45.

Kalhor, R., Asefzadeh, S., Ghamari, F. (2016) "Ranking Eastern Mediterranean Region Countries (EMRO) Based on the Health Impact Indicators Using Multi-criteria Decision Approach", Journal of Biology and Today's World 5(12), s.213-217.

Karabašević, D.,Stanujkić, D., Urošević, S., Maksimović, M. (2016) "An Approach to Personnel Selection based on SWARA and WASPAS Methods", Journal of Economics, Management and Informatics 7(1), s.1-11.

Keršulienė, V., Zavadskas, E. K., Turskis, Z. (2010) "Selection of Rational Dispute Resolution Method by Applying New Step-Wise Weight Assessment Ratio Analysis (SWARA)", Journal of Business Economics and Management 11(2), s.243-258.

Kesgin, C., Topuzoğlu A. (2006) "Sağlığın Tanımı; Başaçıkma”, Journal of İstanbul Kültür University 4(3), s.47-49.

Keshavarz Ghorabaee, M., Zavadskas, E.K., Turskis, Z., Antucheviciene, J. (2016) "A New Combinative Distance-Based Assessment (CODAS) Method for Multi-Criteria Decision-Making", Economic Computation and Economic Cybernetics Studies and Research 3(50), s.25-44.

Kocaman, A. M., Mutlu, E.M., Bayraktar, D., Araz, Ö.M. (2012) “OECD Ülkelerinin Sağlık Sistemlerinin Etkinlik Analizi', Endüstri Mühendisliği Dergisi 23(4), s.14-31.

Kuo, R., Wu Y., Hsu T., Chen L. (2011) "Improving Outpatient Services for Elderly Patients in Taiwan: A Qualitative Study", Archives of Gerontology and Geriatrics 53(2), s.209-217.

Mathew, M.,Sahu S. (2018) "Comparison of New Multi-Criteria Decision Making Methods for Material Handling Equipment Selection", Management Science Letters 8, s.139-150.

Mohamed Riyazh Khan, A., Rajamanoharane, S., Prasad, P. (2012) "Service Quality Performance Measurement Management in Corporate Hospitals Using Analytical Hierarchy Process", International Journal of Manufacturing Technology and Management 26(1-4), s.196-212.

Mut S., Akyürek Ç.E. (2017). "OECD Ülkelerinin Sağlık Göstergelerine Göre Kümeleme Analizi İle Sinıflandırılması”, International Journal of Academic Value Studies, Cilt: 3/12 411-422.

Önder, E., Önder, G., Kuvat, Ö., Taş, N. (2014) "Identifying the Importance Level of Factors Influencing the Selection of Nursing as a Career Choice Using AHP: Survey to Compare the Precedence of Private Vocational High School Nursing Students and Their Parents", Procedia-Social and Behavioral Sciences 122, s.398-404.

Özbek, A. (2017) Çok Kriterli Karar Verme Yöntemleri ve Excel ile Problem Çözümü, Seçkin Yayıncılık, Ankara.

Özdemir A.İ, (2009), "Hizmet Sektörü Etkinliğinin Makro Düzeyde İncelenmesi: Karadeniz Ekonomik İşbirliği Teşkilatı Üyesi Ülkelerin Sağlık Sektörü Üzerine Bir Analiz", Erciyes Üniversitesi İktisadi ve İdari Bilimler Fakültesi Dergisi 33, s.189-205.

Özkan, A. (2013) "Evaluation of Healthcare Waste Treatment/Disposal Alternatives by Using Multi-Criteria DecisionMaking Techniques", Waste Management and Research 31(2), s.141-149.

Retzlaff R., D., Chang C. F., Rubin R., M. (2004). "Technical Efficiency in the Use of Health Care Resources: A Comparison of OECD Countries", Health Policy 69(1), s.55-72.

Ruzgys, A.,Volvačiovas, R., Ignatavičius, Č., Turskis, Z. (2014) "Integrated Evaluation of External Wall Insulation in Residential Buildings Using SWARA-TODIM MCDM Method", Journal of Civil Engineering and Management 20(1), s.103-110.

Shieh, J., Wu, H., Huang, K. (2010) "A DEMATEL Method in Identifying Key Success Factors of Hospital Service Quality", Knowledge-Based Systems 23(3), s.277-282.

Stanujkic, D.,Karabašević, D., Zavadskas, K.E. (2015) "A Framework for the Selection of a Packaging Design based on the SWARA Method" Inzinerine Ekonomika-Engineering Economics 26(2), s.181-187.

Şener, M., Yiğit, V. (2017) "Sağlık Sistemlerinin Teknik Verimliliği: OECD Ülkeleri Üzerinde Bir Araştırma", Süleyman Demirel Üniversitesi Sosyal Bilimler Enstitüsü Dergisi 1(26), s.266-290.

Taghipour, S., Banjevic, D., Jardine, A.S. (2011) "Prioritization of Medical Equipment for Maintenance Decisions", Journal of the Operational Research Society 62(9), s.1666-1687.

Tang, L. (2013) "Helping the Decision Maker Effectively Promote Various Experts Views into Various Optimal Solutions to China's Institutional Problem of Health Care Provider Selection through the Organization of a Pilot Health Care Provider Research System, Health Research Policy and Systems11(1), s.1-20.

Tayalı, H.A. (2017) "Tedarikçi Seçiminde WASPAS Yöntemi", Akademik Sosyal Araştırmalar Dergisi 5(47), s.368-380.

Topaloglu, H., Gumussoy, C., Bayraktaroglu, A., Calisir, F. (2012) "The Relative Importance of Usability and Functionality Factors for E-Health Web Sites", Human Factors and Ergonomics in Manufacturing 19(6), s.336345. 
Tuş Işık, A., Aytaç Adalı. E. (2016) "A New Integrated Decision Making Approach Based on SWARA and OCRA Methods for the Hotel Selection Problem", Int. J. Advanced Operations Management 8(2), s.140-151.

Türeli, N.Ş., Davraz, G.M. (2016) "Hizmet Sektöründeki Personelin Seçiminde AHP ve VIKOR Yönteminin Kullanımı: Özel Hastaneler Açısından Bir İnceleme", The Journal of Academic Social Science Studies 44, s.249-262.

Türkoğlu, S.P. (2018) "Avrupa Ülkelerinin Sağlık Göstergelerinin TOPSIS Yöntemi ile Değerlendirilmesi", AİBÜ Sosyal Bilimler Enstitüsü Dergisi 18(1), s.65-78.

Uyan, M., Yalpır, Ş. (2016) "Çok Kriterli Karar Verme Modeli ve CBS Entegrasyonu ile Tıbbi Atık Sterilizasyon Tesislerinin Yer Seçimi", Afyon Kocatepe Üniversitesi Fen ve Mühendislik Bilimleri Dergisi 6, s.642-654.

Vesković, S., Stević, Ž. Stojić, G., Vasiljević, M., Milinković, S. (2018) "Evaluation of the Railway Management Model by Using A New Integrated Model DELPHI-SWARA-MABAC", Decision Making: Applications in Management and Engineering 1(2), s.34-50.

Whiting D. R., Guariguata L., Weil C., Shaw J. (2011). "Diabetes Atlas: IDF Diabetes Atlas: Global Estimates of the Prevalence of Diabetes for 2011 and 2030", Diabetes Research and Clinical Practice 94(3), s.311-321.

Wollmann, D., Steiner, M., Vieira, G., Steiner, P. (2014) "Details of the Analytic Hierarchy Process Technique for the Evaluation of Health Insurance Companies", Producao 24(3), s.583-593.

Word Healty Organization (2018). https://www.who.int/gho/countries/en/ (31.10.2018).

Yurdoğlu, H., Kundakcı, N. (2017) "SWARA ve WASPAS Yöntemleri ile Sunucu Seçimi", Balıkesir Üniversitesi Sosyal Bilimler Enstitüsü Dergisi 20(38), s.161-173.

Zavadskas, E.K., Kalibatas, D., Kalibatiene, D. (2016) "A Multi-Attribute Assessment Using WASPAS for Choosing an Optimal Indoor Environment", Archives of Civil and Mechanical Engineering, 76-85.

Zavadskas, E. K., Turskis, Z., Antucheviciene, J., Zakarevicius, A. (2012) "Optimization of Weighted Aggregated Sum Product Assessment", Elektronika ir Elektrotechnika 122(6), s.3-6.

Zolfani, H.S., Zavadskas, K.E. (2013) "Sustainable Development of Rural Areas' Building Structures Based on Local Climate", Procedia Engineering 57, s.1295-1301.

Zolfani, H.S., Zavadskas, K.E., Turkish, Z. (2013) "Design of Products with Both International and Local Perspectives based on Yin-Yang Balance Theory and SWARA Method", Economic Research-Ekonomska Istraživanja 26(2), s.153-166.

Zolfani, S. H., Bahrami, M. (2014) "Investment Prioritizing in High Tech Industries based on SWARA-COPRAS Approach", Technological and Economic Development of Economy 20(3), s.534-553. 